\title{
Titanium dioxide dental implants surfaces related oxidative stress in bone remodeling: A systematic review
}

\author{
Elaf Abdulhameed ${ }^{\text {Corresp., 1, }}{ }^{,}$, Natheer H Al-Rawi ${ }^{3}$, Marzuki Omar ${ }^{1}$, Nadia khalifa ${ }^{2}$, AB Rani Samsudin ${ }^{3}$ \\ ${ }^{1}$ School of Dental Sciences, Universiti Sains Malaysia, Kelantan, Malaysia \\ 2 Preventive and Restorative Dentistry, College of Dental Medicine, University of Sharjah, Sharjah, United Arab Emirates \\ 3 Oral and Craniofacial Health Sciences, University of Sharjah, Sharjah, United Arab Emirates \\ Corresponding Author: Elaf Abdulhameed \\ Email address: Ealzubaidi@sharjah.ac.ae
}

Background: : Titanium dioxide dental implants have a controversial effect on reactive oxygen species (ROS) production. ROS is necessary for cellular signal transmission and proper metabolism, but also has the ability to cause cell death as well as DNA, RNA, and proteins damage by excessive oxidative stress. This study aimed to systematically review the effect of titanium dioxide dental implant-induced oxidative stress and its role on the osteogenesis-angiogenesis coupling in bone remodeling. Methods: This systematic review was performed conforming to preferred reporting items for systematic review and meta-analysis (PRISMA) model. Four different databases (PubMed, Science Direct, Scopus and Medline databases) as well as manual searching were adopted. Relevant studies from January 2000 till September 2021 were retrieved. Critical Appraisal Skills Programme (CASP) was used to assess the quality of the selected studies. Results: Out of 755 articles, only 14 which met the eligibility criteria were included. Six studies found that titanium dioxide nanotube (TNT) reduced oxidative stress and promoted osteoblastic activity through its effect on Wnt, mitogen-activated protein kinase (MAPK) and forkhead box protein $\mathrm{Ol}$ (FoxO1) signaling pathways. On the other hand, three studies confirmed that titanium dioxide nanoparticles ( $\mathrm{TiO}_{2} \mathrm{NPs}$ ) induce oxidative stress, reduce ostegenesis and impair antioxidant defense system as a significant negative correlation was found between decreased SIR3 protein level and increased superoxide $\left(\mathrm{O}_{2}{ }^{-}{ }^{-}\right)$. Moreover, five studies proved that titanium implant alloy enhances the generation of ROS and induces cytotoxicity of osteoblast cells via its effect on NOX pathway.

Conclusion: $\mathrm{TiO}_{2} \mathrm{NPs}$ stimulate a wide array of oxidative stress related pathways. Scientific evidence are in favor to support the use of $\mathrm{TiO}_{2}$ nanotube-coated titanium implants to reduce oxidative stress and promote osteogenesis in bone remodeling. To validate the cellular and molecular cross talk in bone remodeling of the present review, a well-controlled clinical trials with large sample size are required.

It is registered with the appropriate guideline protocol with the International Prospective Register of Systematic Reviews (PROSPERO) platform (ID: CRD42021271610). 

angiogenesis coupling in bone remodeling.

\section{Titanium dioxide dental implants surfaces related oxidative stress in bone remodeling: A systematic review}

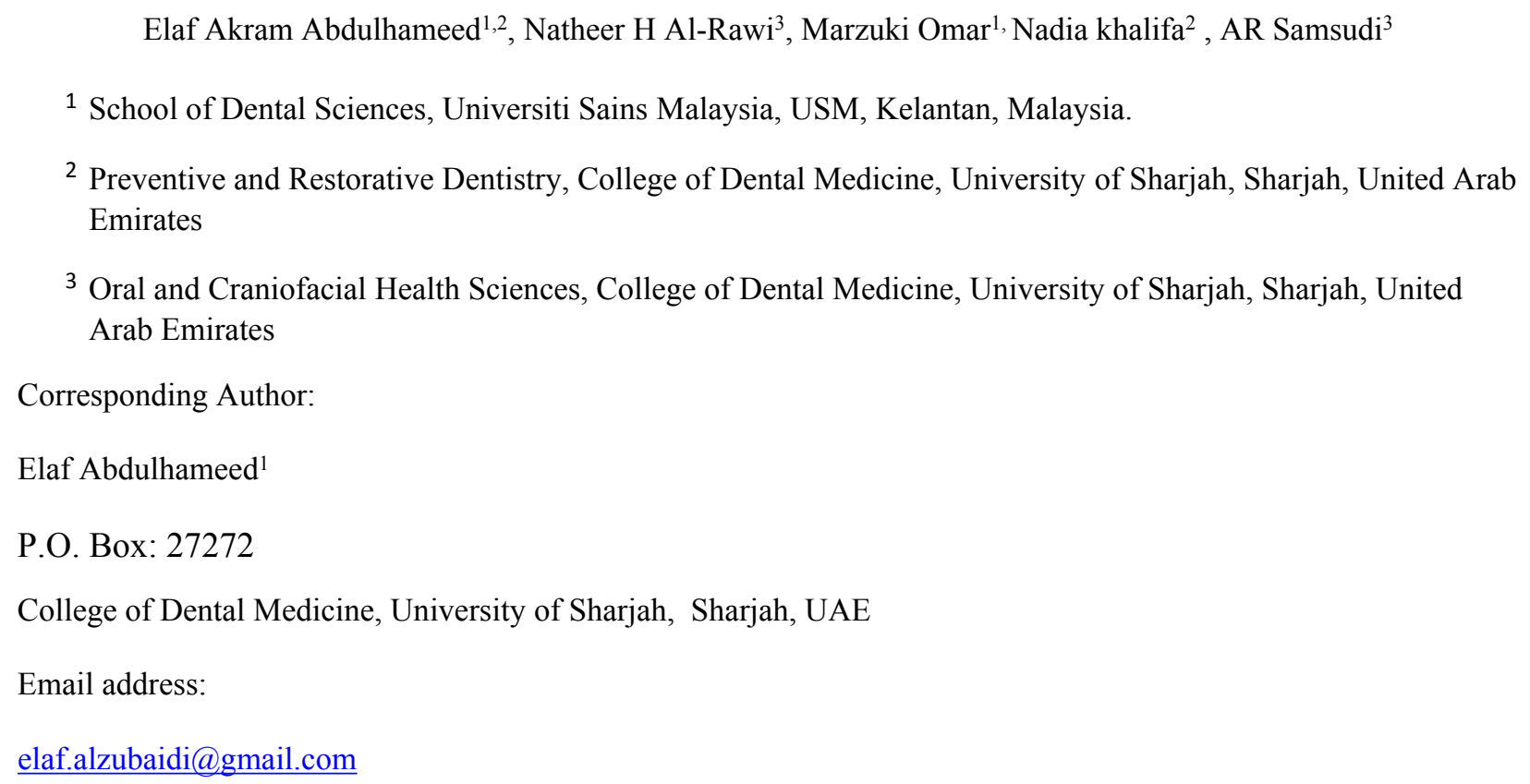

Background: : Titanium dioxide dental implants have a controversial effect on reactive oxygen species (ROS) production. ROS is necessary for cellular signal transmission and proper metabolism, but also has the ability to cause cell death as well as DNA, RNA, and proteins damage by excessive oxidative stress. This study aimed to systematically review the effect of titanium dioxide dental implant-induced oxidative stress and its role on the osteogenesis-

Methods: This systematic review was performed conforming to preferred reporting items for systematic review and meta-analysis (PRISMA) model. Four different databases (PubMed, Science Direct, Scopus and Medline databases) as well as manual searching were adopted. Relevant studies from January 2000 till September 2021 were retrieved. Critical Appraisal Skills Programme (CASP) was used to assess the quality of the selected studies. 
26 Results: Out of 755 articles, only 14 which met the eligibility criteria were included. Six studies

27 found that titanium dioxide nanotube (TNT) reduced oxidative stress and promoted osteoblastic

28 activity through its effect on Wnt, mitogen-activated protein kinase (MAPK) and forkhead box

29 protein $\mathrm{O} 1$ (FoxO1) signaling pathways. On the other hand, three studies confirmed that

30 titanium dioxide nanoparticles $\left(\mathrm{TiO}_{2} \mathrm{NPs}\right)$ induce oxidative stress, reduce ostegenesis and

31 impair antioxidant defense system as a significant negative correlation was found between

32 decreased SIR3 protein level and increased superoxide $\left(\mathrm{O}_{2}{ }^{--}\right)$. Moreover, five studies proved

33 that titanium implant alloy enhances the generation of ROS and induces cytotoxicity of

34 osteoblast cells via its effect on NOX pathway.

35 Conclusion: $\mathrm{TiO}_{2} \mathrm{NPs}$ stimulate a wide array of oxidative stress related pathways. Scientific

36 evidence are in favor to support the use of $\mathrm{TiO}_{2}$ nanotube-coated titanium implants to reduce

37 oxidative stress and promote osteogenesis in bone remodeling. To validate the cellular and

38 molecular cross talk in bone remodeling of the present review, a well-controlled clinical trials with

39 large sample size are required.

40 Keywords: Angiogenesis, nanoparticles, nanotube, ROS, Osteogenesis, $\mathrm{TiO}_{2}$. 
41

42

43

44

\section{Introduction}

Injury, infections and malignancies of maxillofacial region cause defects in hard and soft tissues. Small defects heal on their own in healthy people, while big defects require scaffolded dental implant to allow for sufficient hard and soft tissue regeneration (Zeng et al., 2018). The diagnostic imaging technology has witnessed a giant revolution in the last three decades. With the introduction of 3D imaging, the hard tissue regeneration can be visualized in all planes rather than using a two-dimensional evaluation (Hans et al., 2015). CBCT evaluation is one of the non-invasive, well suited method to analyze and evaluate bone texture and regeneration on a valuable modality that precisely evaluates skeletal components in the craniofacial region with a 1:1 image (no magnification) (Alhammadi et al., 2021). However, it is of limited value in the assessment of soft tissue facial characteristics (Ludlow et al., 2007; Kitai et al., 2017).

between craniofacial measurements obtained from the gold standard cephalometric adiographs and analogous measurements from standardized facial profile photographs. They found the standardized photographic method to be repeatable and reproducible. Further, they considered it to be a feasible and practical non-invasive alternative diagnostic method so long as the standardized protocol is followed. Another study concluded that the soft tissue analysis on photographs is a reliable method to evaluate the soft tissue profile compared to the analyses performed on cephalograms (Nucera et al., 2017). 
61 Dental implants are foreign bodies that when implanted in bone tissue will lead to generation

of Reactive Oxygen Species (ROS). ROS in physiological amount is needed for cellular signal transduction and physiological metabolism. However when the generation of ROS exceed the antioxidant capacity, oxidative stress develop and normal tissue haemostasis imbalance occur leading to poor tissue regeneration and wound healing (Lee et al., 2021).

The reactive oxygen species (ROS) is an unstable oxygen-containing molecule that interacts with other molecules in the cell. Its reaction has the ability to cause cell death as well as DNA, RNA, and proteins damage (Srinivas et al., 2019). ROS is necessary for cellular signal transmission and proper metabolism in physiological quantities. Oxidative stress occurs when ROS production exceeds antioxidant capacity, disrupting normal tissue homeostasis and resulting in poor tissue regeneration and wound healing (Huang et al., 2021).

2 Bone is a metabolically active structure because it undergoes continual remodeling throughout life. This remodeling occurs as a result of bone resorption and deposition. Biomolecules called Bone Turnover Markers (BTMs) are released into the blood during bone resorption and deposition (Carey et al., 2006). The presence of the dental implants in oral tissues greatly alters their function, this is visible through the analysis of the inflammation markers present, in a study performed by Guarnieri et al., (2021) to compare gingival tissue healing at surgically manipulated periodontal sites and at sites receiving implants and healing abutments with machined (MS) vs lasermicrotextured (LMS) surface placed with one-stage protocol. He concluded that both MS and LMS implant sites presented a higher pro-inflammatory state in the early phase after surgery (1-4 weeks). At 12 weeks, only MS implant sites kept a higher pro-inflammatory state, while at LMS 
82 implant sites, it becomes similar to surgically and non-surgically manipulated periodontal tissues

83 (Guarnieri et al., 2021).

84 Bone resorption process takes around ten days to take place, whereas bone formation takes

85 around two months to heal or replace the deficiency. As a result, osteoclastic activity is faster than

86 osteoblastic activity, posing a challenge to surgeons and scientists when it comes to bone and

87 skeletal repair and regeneration (Mizuno \& Glowacki, 2000).

88 The formation of new blood vessels is critical for bone metabolism, modeling, and remodeling,

89 particularly in osteogenesis and bone repair, as seen in bone fracture healing, for example

90 (Kanczler \& Oreffo, 2008; Santos \& Reis, 2010). Angiogenesis, which is the sprouting of new

91 arteries from pre-existing ones after activation of endothelial and vessel wall stem cells, and

92 osteogenesis, which is the induction of progenitor cells into the osteoblast lineage, are closely

93 coupled. An autocrine and paracrine network of factors generated by osteoblasts, endothelial cells,

94 and their progenitors regulates the interaction between osteogenesis and angiogenesis (Riddle et 95 al., 2009).

96 Under physiological settings, regulatory proteins and proper signal transductions closely 97 govern all these components that orchestrate bone repair. When bone cells are exposed to oxidative 98 stress which are released as a result of damage, bacterial toxins, or bone augmentation in bone grafting surgery procedures, ROS may impede or undermine the complicated bone regeneration process (Wauquier et al., 2009) (Figure 1).

Dental implants are commonly used in dentistry, orthopedic surgery and other specialties that work on human skeleton (Sayed et al., 2021). Biocompatibility properties of these materials have 103 been studied extensively. However, there is debate over the function of ROS in the remodeling 104 process and the dental implants' long-term stability. The key function of ROS in angiogenesis- 
105 106

107

108

109

110

111

112

113

114

115

116

117

118

119

120

121

122

123

124

125

126

osteogenesis coupling may influence the effectiveness of dental implant osseointegration because bone is a highly vascularized tissue (Hu et al., 2018). There has recently been a growing body of evidence demonstrating the link between ROS generation during intraosseous dental implant implantation and bone vascularization and remodeling. The primary objective of this systematic review is to estimate the extent of ROS release after dental implant placement in bone and its impact on bone remodeling.

\section{Materials and methods}

\subsection{Protocol Registration:}

This systematic review was conducted with the standard regulations of Preferred Reporting Items for Systematic Reviews and Meta-Analysis (PRISMA) statement. It is registered with the appropriate guideline protocol with the International Prospective Register of Systematic Reviews (PROSPERO) platform (ID: CRD42021271610).

\subsection{Focused Question}

Does dental implants-induced oxidative stress have an effect on bone remodeling?

The current systematic review was adopted to follow PICO criteria;

P: Patient who underwent biomaterial placement using either nanoparticles or nanotube.

I: Intervention; two different biomaterials were used nanoparticles and nanotube.

C: Comparison on the amount of oxidative stress release from the two biomaterials.

O: Oxidative stress release amount from the two biomaterials.

\subsection{Search Strategy}

Four databases were used for this systematic review (PubMed, Science Direct, Scopus and Medline). The search included the following sets of key words like: (Oxidative stress) or (Reactive 
127 oxygen species); (Titanium dioxide nanoparticles); (Titanium dioxide nanotube); (Titanium alloy);

128 (Osteogensis); (Angiogenesis) or (VEGF). The mesh term used was (Titanium dioxide

129 nanoparticles AND oxidative stress); (Titanium dioxide nanotubes AND oxidative stress);

130 (Titanium alloy AND oxidative stress); (Bone regeneration AND oxidative stress), (Oxidative

131 stress AND bone regeneration); (Titanium dioxide nanoparticles, oxidative stress AND

132 osteogenesis-angiogenesis coupling); (Titanium dioxide nanotubes, oxidative stress AND

133 osteogenesis-angiogenesis coupling); (Dental implant, oxidative stress AND osteogenesis-

134 angiogenesis coupling).

135 The search terms employed were key words classified under the general (all fields) category.

136 The search terms were combined with an 'OR' and categories were combined using 'AND' or

137 'NOT' to create a final search query. The following filters were applied to these terms: Full text, 138 published in the last 21 years (since 2000), English and academic literatures only. Two 139 independent reviewers (EAA and NHA) conducted the search from April 2021 to September 2021.

$140 \quad 2.5$. Inclusion and exclusion criteria

$141 \quad$ 2.5.1 Inclusion criteria:

Full text papers published in English literature. All clinical investigations on oxidative stress, dental implant, bone regeneration, and osteogenesis-angiogenesis coupling that were conducted in vivo, in situ, in vitro, or in cell culture met the inclusion criteria for the period from

145 January 2000 till September 2021.

\subsubsection{Exclusion criteria:}

147 Studies that did not highlight the influence of oxidative stress on dental implant, bone 148 regeneration, or osteogenesis-angiogenesis coupling were excluded. Studies that did not look at 
149 cross talk in the context of bone remodeling in the presence of oxidative stress were also 150 eliminated.

151

152

153

154

155

156

157

158

159

160

161

162

163

164

165

166

167

168

169

170

171

172

\subsection{Eligibility Criteria}

In order to obtain precise results, clinical studies and clinical trials were included in this study. Papers that have been peer reviewed were selected as well. The aim of those selected studies is to figure out whether dental implant-induced oxidative stress influence the osteogenesisangiogenesis coupling in bone remodeling. Articles involving expert's opinions were excluded. Abstract in conferences, and letters to editors found in articles were also excluded, as well as nonpeer reviewed and non-English papers.

\subsection{Data Extraction}

The papers selected from four databases (PubMed, Science Direct, Scopus and Medline) were reviewed by two authors separately (EAA and NHA). This procedure was completed through the following steps. First, after selecting the papers from database search, duplicated papers were removed manually. Secondly, each person read through the abstract of the paper, selecting them based on the inclusion and exclusion criteria. The final step included reading full text paper. Screening was conducted by two authors independently (EAA and NHA.) and any disagreement was resolved via discussion with a third reviewer (RS) to reach a consensus. Level of inter-reviewer agreement was determined by Cohen Kappa score. Article meeting (McHugh, 2012) the eligibility criteria were included for quality. Then data were extracted from each one including name of author/year, aim of the study, design, sample characteristics, interventions, and assaying OS levels.

\subsection{Studies quality assessment}


174 assessed the quality of the included studies. The CASP tool is a generic tool for appraising

175 the strengths and limitations of any qualitative research paper. To assess the quality of the

176 study, three different domains (Introduction, methodology, results and discussion) was used.

177 A tick scroing system was used for each study. In CASP, there are 30 questions for the three

178 domains, each question score 3.33. The studies were graded as "Strong," "Moderate," and

179 "Weak" based on the total CASP score. Studies that scored less than $33 \%$ were considered

180 weak, between $33 \%$ and $67 \%$ were considered moderate and higher than $67 \%$ were 181 considered an article of strong evidence.

182

183

184

185

186

187

188

189

190

191

192

193

194

195

\subsection{Analysis}

A descriptive summary of the findings are tabulated based on the focused question as seen in Table (1). CASP score was used to assess the quality of each study.

\subsection{Data analysis}

Due to heterogeneity among selected studies, formal quantitative synthesis metaanalysis was not conducted.

\section{Results}

\subsection{Study selection}

A preliminary database search yielded 750 papers. A manual search resulted in the discovery of five papers. After eliminating duplicate records, 446 records matched the inclusion criterion. Based on the exclusion criteria, 432 papers were eliminated after screening the abstracts. Finally, 14 papers were eligible for qualitative analysis. Reasons for excluding the studies are depicted in the PRISMA as shown in Figure (2). Detailed characteristics of each study are depicted in Table (1). 
196

197

198

199

200

201

202

203

204

205

206

207

208

209

210

211

212

213

214

215

216

217

218

\subsection{Study quality assessment}

We graded all the selected papers after the critical appraisal was completed. Eleven of them were rated as papers of strong evidence ranged from $70 \%$ to $98.33 \%$. Three papers were rated as papers of moderate evidence ranged from $61.66 \%$ to $65 \%$.None of the studies were with weak evidence as shown in Table (2).

Two authors performed the quality appraisal of the included papers (EAA and NHA). For RCT, the quality of the included studies were assessed using the Cochrane Risk of Bias tool (RoB2) (Sterne et al., 2019). A total of five domains are examined for the RoB2 test, with judgments ranging from minimal risk of bias to some concerns and to high risk of bias. The overall risk of bias usually corresponds to the worst risk of bias in any of the domains. (Figure 3) For non-randomized clinical trials, two authors (MO and RS) used ROBINS-I instrument to assesses a total of seven domains, with low risk, moderate risk, severe risk, and critical risk of bias being the judgments. The low risk of ROBINS-I corresponds to a high-quality non-randomized study. Overall, for low risk, the study is judged to be at low risk of bias for all domains; for moderate risk, the study is judged to be at low/moderate risk of bias for all domains; for serious risk, the study is judged to be at serious risk of bias in at least one domain, but not at critical risk of bias in any domain and for critical risk, the study is judged to be at critical risk of bias in at least one domain (Figure 4).

$$
\text { In vitro studies included in this review were assessed with the tool developed by }
$$
the United States national toxicology program (Rooney, 2015). The tool consists of seven criteria (i) Experimental condition bias; (ii) blinding during study; (iii) incomplete data; (iv) exposure characterization (v) Outcome assessment (vi) Reporting bias (vii) Other. 
219 The interpretation for fulfilling a "moderate," "low," and "no information" score was

220 described in Figure (5).

221

222

223

224

225

226

227

228

229

230

231

232

233

234

235

236

237

238

239

240

241

\subsection{Studies characteristics}

All the studies that were included took place between the years of 2000 and 2021. Of the fourteen studies, five publications were undertaken in vitro; most of them were performed in China (Zhang et al., 2011; Xie et al., 2014; Yu et al., 2018; Shen et al., 2019) and only one was performed in Poland (Niska et al., 2015). Other five studies were conducted in vitro/vivo, three of them performed in China (Hu et al., 2018; Yang et al., 2020; Huang et al., 2021), One in Saudi Arabia (El-Shenawy, Mohsen \& Fadl-Allah, 2012) and one in Korea (Lee et al., 2013). The last four studies were done in humans and, three of them performed in Italy (Pietropaoli et al., 2013; Mariarosaria et al., 2017; Mijiritsky et al., 2019) and one in Poland (Borys et al., 2018). All these fourteen studies studied the effect of titanium dioxide nanoparticles, nanotubes and titanium alloy on the generation of ROS and osteogenesis along with the relevant affected signaling pathways such as Wnt, MAPK and NOX pathway.

\subsection{Study Outcome}

The fourteen articles that were chosen did not all shed the light on the same type of titanium dioxide, in fact 6 of those (El-Shenawy, Mohsen \& Fadl-Allah, 2012; Lee et al., 2013; Yu et al., 2018; Shen et al., 2019; Yang et al., 2020; Huang et al., 2021) focused on of titanium dioxide nanotube effect on oxidative stress and osteogenesis and 3 studies (Zhang et al., 2011; Xie et al., 2014; Niska et al., 2015) focused on the effect of titanium dioxide nanoparticles on oxidative stress and osteogenesis therefore, highlighting theses results were done first.

\subsubsection{TNT Effect on Oxidative stress}


243 superior osteogenic differentiation of bone mesenchymal stem cells (MSCs) and osseointegration

244 compared with microscale sand blasted-acid etched topography (SLA) (Huang et al., 2021).

245 Huang et al. in their study found that the increased forkhead box transcription factor O1 (FoxO1)

246 drives oxidation resistance on TNT during oxidative stress (OS) and TNT decreases oxidative

247 stress (OS) in macrophages indirectly, leading in a higher proportion of the M2 phenotype under

248 OS and increased secretion of the antiinflammatory cytokine IL-10 could improves osseo-

249 immunity capability in contrast to SLA (Huang et al., 2021). Shen et al. in their study on cell

250 culture confirmed that large nanotubes $(110 \mathrm{~nm})$ were shown to greatly aggravate early

251 inflammatory responses of RAW264.7 cells by up-regulating ITG-mediated MAPK and NFkB

252 pathways. This further increased the expressions of osteogenesis and chemokine genes like BMP2,

253 VEGF, IL-8, SDF1 and CCL2. (Shen et al., 2019) Co-culture of RAW264.7 with MSCs results in

254 more MSCs that were effectively recruited by inflammatory RAW264.7 cells on TNT110

255 substrates which secretes many antiinflammatory cytokines like such as IL-4, IL-10, IL-13, and

256 TGF $\beta 1$ which suppresses inflammation of RAW264.7 cells by increasing M1-to-M2 transition.

257 Crosstalk between MSCs and RAW264.7 cells caused by $110 \mathrm{~nm}$ nanotubes was found to be the

258 key factor promoting early osteogenic induction in the TNT110 group (Shen et al., 2019). Yu et

259 al. in their study on calvaria osteoblasts seeded onto different substrates investigated the anti-

260 oxidative properties of various $\mathrm{TiO}_{2}$ nanotubes (TNTs) to screen the desirable size for improved

261 steogenesis and reveal the underlying molecular mechanism. He discovered that oxidative stress

262 resistance of large $\mathrm{TIO}_{2}$ nanotubes was linked to high expression of integrin 51 (ITG 51), which

263 up-regulated the production of anti-apoptotic proteins (p-FAK, p-Akt, p-FoxO3a, and Bcl2) while

264 down-regulating the expression of pro-apoptotic proteins (p-FAK, p-Akt, p-FoxO3a (Bax). Wnt 
265 signals on the other hand like Wnt3a, Wnt5a, Lrp5, Lrp6, and -catenin have also been discovered

266 to play a function in encouraging osteogenic differentiation of osteoblasts in oxidative stress

267 condition ( $\mathrm{Yu}$ et al., 2018). El-Shenawy et al. used $\mathrm{TiO}_{2}$ nanotube and Ti-plate in rats as an

268 artificial surgical implant, they found that $\mathrm{TiO}_{2}$ nanotube did not induce elevation of MDA in liver

269 and kidney tissues, however, some antioxidant have been changed. However, $\mathrm{TiO}_{2}$ nanotube has

270 less effect on the redox state of rat than Ti-plate for use as an artificial surgical implant (El-

271 Shenawy, Mohsen \& Fadl-Allah, 2012). In 2013, Lee et al., examined the effect of N-acetyl

272 cysteine (NAC)-loaded nanotube titanium (NLN-Ti) implants on antioxidants enzymes and bone

273 formation. MC-3T3-E1 cells were seeded on pure Ti and nanotube Ti surfaces increased the

274 expression of RANKL and markedly diminished the expressions of bone morphogenic protein

275 BMP-2, -7. Lee et al. found that NAC-loaded nanotube Ti (NLN-Ti) surfaces attenuated the level

276 of RANKL expression and expression of antioxidants enzymes and bone formation molecules,

277 such as BMP-2 and -7.(19) Yang et al.also investigated if titanium implants with $\mathrm{TiO}_{2}$ nanotubes

278 (TNT) surface can retain their biocompatibility and osteogenetic ability under diabetic conditions

279 in rats, they found that high-glucose conditions in diabetic rats inhibited alkaline phosphatase

280 (ALP) and osteopontin (OPN) on different modified Ti surfaces, as TNT surface could alleviate

281 the inhibition ALP and OPN expressions under high-glucose conditions. High-glucose conditions

282 inhibited osteogenesis on different modified Ti surfaces, The TNT surface could alleviate the

283 inhibition of mineralization when compared with the SLA surface under high glucose conditions

284 (Yang et al., 2020).

285

3.4.2 $\mathrm{TiO}_{2} \mathrm{NP}$ Effect on Oxidative stress

286

In 2015, Niska et al. subjected hFOB 1.19 cells to $\mathrm{TiO}_{2} \mathrm{NPs}$ and found that $\mathrm{TiO}_{2} \mathrm{NPs}$ 
288 cellular processes, it protects cells against stress and control a number of metabolic pathways) in

289 osteoblast cells (Niska et al., 2015). They found a significant positive correlation between SIR3

290 and MnSOD at the protein level and a significant negative correlation was found between

291 decreased SIR3 protein level and increased superoxide $\left(\mathrm{O}_{2}{ }^{-}\right)$level. They concluded that TiO ${ }_{2} \mathrm{NP}-$

292 could induce toxicity in osteoblast cells (Niska et al., 2015).

MC3T3-E1 murine preosteoblasts seeded on $\mathrm{TiO}_{2} \mathrm{NPs}$ of 5 and $32 \mathrm{~nm}$ in diameter to assess the cytotoxic effects of $\mathrm{TiO}_{2}$ nanoparticles (NPs) of different sizes on murine MC3T3-E1

preosteoblasts. Therefore several tests were conducted like cell viability and cytotoxicity assays,

murine pre-osteoblast cells to $\mathrm{TiO}_{2}-\mathrm{NPs}$, the the survival rate of the osteoblast decreased and the content of the lactate dehydrogenase (LDH) released by the cell increased (Zhang et al., 2011; Xie et al., 2014).

300

301

302

303

304

305

306

307

308

309

\subsubsection{Other Titanium alloy effect on oxidative stress}

Borys et al. performed a study to evaluate the influence of Ti6Al4V titanium alloy on redox balance and oxidative damage in the periosteum surrounding the titanium miniplates and screws as well as in plasma and erythrocytes of patients with mandibular fractures. In their study they found that the occurrence of redox imbalance as well as oxidative stress and oxidative damage in the periosteum surrounding the Ti6Al4V titanium alloy has increased, as well as activity/concentration of antioxidants both in the mandibular periosteum and plasma/erythrocytes of patients with titanium mandibular implants (Borys et al., 2018).

\subsubsection{Effect of local and systemic factors on oxidative stress around implants}



and oxidative stress in periimplantitis, they compared subjects with chronic periodontitis and

312 periimplantitis to healthy subjects and they found that subjects with periodontitis had significantly 313 higher oxidative stress than periimplantitis and healthy groups, and that subjects with 314 periimplantitis had significantly higher oxidative stress than healthy subjects. To confirm the 315 presence of ROS in inflammatory meliue of peri-implantitis tissue, Mijiritsky et al., In 2019, 316 conducted a cross-sectional study on patients with peri-implantitis (in which circumferential peri317 implant soft tissue samples were collected during respective surgical treatment of peri-implantitis 318 or in case of extraction of failed implants due to peri-implant disease) and patients with healthy periodontium (a specimen of mucosa was collected from the healing abutment at the second stage of implant uncovery). They suggested that peri-implantitis lesions exhibit a well defined biological organization not only in terms of inflammatory cells but also on vessel and extracellular matrix components even if no difference in the epithelium is evident, and the presence of reactive oxygen species (ROS) related to the inflammatory environment influences the correct commitment of mesenchymal stem cells as confirmed by Immunohistochemistry and histomorpholgical analyses, immunofluorescence staining and Transmission Electron Microscopy (TEM) (Mijiritsky et al., 2019).

Mariarosaria et al., in 2017 evaluated the presence of oxidative stress during peri-implant bone resorption in immediate post-extractive implant, they found an increase in both oxidative stress markers and cyclooxygenase-2 expression during implant integration for the period between the first and third week, however at sixteenth week the parameters evaluated returned to basal values (Mariarosaria et al., 2017). Finally, Hu et al in 2018 highlighted the role of angiogenesis in the diabetes-induced poor bone repair at the bone-implant interface (BII) and the related mechanisms. 
333 They suggested that the advanced glycation end products (AGEs)-related and NOX-triggered

334 cellular oxidative stress leads to vascular endothelial cell (VEC) dysfunction and angiogenesis

335 impairment at the bone-implant interface (BII), which plays a critical role in the compromised

336 implant osteointegration under diabetic conditions (Hu et al., 2018).

\section{4. Discussion}

High quality and quantity of bone regeneration is the ultimate aim of an implanted

biomaterial. Surgical trauma leading to inflammation is natural sequalae during implantation

procedure generating ROS that is necessary to drive multiple signal transduction for molecular

healing process (Yanez et al., 2017). Very often the site of implantation needing repair has already

been infected and a certain degree of ROS production has already pre-existed even before surgical

implantation of biomaterial (Mouthuy et al., 2016). Combination of pre-existing ROS together

with postoperative implantation trauma may produce an amount of oxidative stress that may

exceed the antioxidant capacity in that particular site. This challenges may lead to inadequate bone

implant integration and without further support with anti-inflammatory and antibiotics and

347

adjustment of loading forces may lead to failure of osseointegration (Yanez et al., 2017). However, the mechanism regulating the interaction between ROS and peri-implant environment with respect to producing ideal integration is poorly understood. Various molecular processes that interact with the biomaterial surface topography, peri-implant tissues, angiogenesis and antioxidants measures have been implicated in this systematic review.

The communication between bone-forming osteoblasts and bone resorbing osteoclasts as well as vascular endothelial cells is a fundamental requirement for effective and balanced bone remodeling (Yin et al., 2021). For biomaterial research in manufacturing novel implant, development of in vitro models is necessary to investigate this communication. 
357 followed by protein adsorption, adhesion and activation of immune cells, and ultimately

358 recruitment of fibroblasts and formation of a fibrous capsule (Liu et al., 2011). During this process,

359 it is thought that reactive oxygen species (ROS) are released by activated phagocytes, and

360 contribute to oxidative degradation of materials (Liu et al., 2011). In this systematic review, most

361 studies found that dental implant enhances ROS generation and reduces osteoblastic activity

362 (Zhang et al., 2011; Pietropaoli et al., 2013; Xie et al., 2014; Niska et al., 2015; Mariarosaria et

363 al., 2017; Borys et al., 2018; Hu et al., 2018; Mijiritsky et al., 2019). Interestingly, some studies

364 have stated that implant nanotubes could act as antioxidant and promote ossteogenesis (El-

365 Shenawy, Mohsen \& Fadl-Allah, 2012; Lee et al., 2013; Yu et al., 2018; Shen et al., 2019; Yang

366 et al., 2020; Huang et al., 2021). However, this area requires further research.

367 Garrett et al. first described the relationships between oxygen-derived free radicals

368 (particularly the superoxide anion) and the formation and activation of osteoclasts (IR et al., 1990).

369 These findings were confirmed by the study of Lee et al in 2005 who demonstrated that the

370 receptor activator of nuclear factor-kappaB ligand (RANKL)-induced osteoclastogenesis requires

371 ROS production. Bone marrow (BM) precursor cells was used as an osteoclast differentiation

372 model (XC et al., 2005). Similarly, osteoblasts play important roles in osteoclastogenesis through

373 regulating receptor activated nuclear factor kappa B (RANK) ligand (RANKL) and

374 osteoprotegerin (OPG) expression. It was hypothesized that OPG plays an important role in the

375 crosstalk between osteoclasts and osteoblasts in response to biomaterial implantation. The

376 evidences from the in vitro and in vivo studies suggested that OPG played an important role in the

377 uncoupling effect of biomaterial on host bone cells metabolism, possibly by acting as a cross-talk

378 molecule between osteoclasts and osteoblasts in response to biomaterial implantation figure (6). 
Recent studies reporting on co-cultures of osteoblasts and osteoclast used different cell combinations. (Borciani et al., 2020) Some authors report on successful cultures of osteoblast cell

381

382

383

384

lines or primary osteoblasts in combination with peripheral blood mononuclear cell (PBMC) or isolated monocytes. The cells were of murine or human origin and were cultivated with or without the addition of M-CSF and RANKL (Borciani et al., 2020). However, there is not much work in regenerative medicine dealing with co-cultures for investigating the impact of ROS secondary to biomaterial are known.

Oxidative stress can affect osteogenesis-angiogenesis coupling by its effect on VEGF signalling. (Y et al., 2013) VEGF exerts its action through binding to VEGF Receptor-2 (VEGFR2, also known as FLK1/KDR) in endothelial cells (ECs), causing autophosphorylaion of EC in its cytoplasmic tyrosine residues and driving downstream pathway such as PI3K/AKT and MAPK which promote EC proliferation and migration. VEGF stimulates ROS production via Rac-1mediated NADPH oxidase activation (Y et al., 2013) and also increases mitochondria-derived $\mathrm{H}_{2} \mathrm{O}_{2}$ (Y et al., 2013).

Based on the above results, there were conflicting findings of the effects of titanium dioxide dental implants on osteogenesis-angiogenesis coupling. Some reports says that TNT enhances OS and impairs osteogenesis -angiogenesis coupling and others says that TNT reduces OS. Studies with strong evidence (Yu et al., 2018; Shen et al., 2019; Huang et al., 2021) were in favor to use titanium dioxide nanotube to reduce oxidative stress and promote osteogenesis-angiogenesis coupling, through activation of Wnt signalling pathways as depicted in figure (6).

Limitations of this review were the small sample sizes and the few clinical trials in most studies, which raises the concern over the reliability of the results. Secondly, the molecular pathways that were affected by dental implant induced-oxidative stress and the effect of oxidative 
402 stress on the osteogenesis-angiogenesis coupling in bone remodeling were not identified in some

403 studies. Additionally, there was a lack of proper statistical tests in some studies, making

404 determining the significance of ROS generation difficult.

405 5. Conclusion

406 Titanium dioxide nanotube (TNT) can reduce oxidative stress and promote osteoblastic activity

407 through its effect on Wnt, MAPK and FoxO1 signaling pathways. Current scientific evidence is

408 inclined towards supporting the use of $\mathrm{TiO}_{2}$ nanotube-coated titanium implants to reduce oxidative stress

409 and promote osteogenesis. . However, more well-designed large sample sized randomized controlled

410 clinical trials are necessary to support our conclusion.

\section{Sources of Funding}

412 This systematic review is not funded by any organization.

\section{Declaration of interests}

414 The authors declare that they have no known competing financial interests or personal 415 relationships that could have appeared to influence the work reported in this paper. 


\section{References:}

417 Alhammadi, M. S., Al-Mashraqi, A. A., Alnami, R. H., Ashqar, N. M., Alamir, O. H., Halboub, 418 E., Reda, R., Testarelli, L. \& Patil, S. (2021) Accuracy and Reproducibility of Facial

419 Measurements of Digital Photographs and Wrapped Cone Beam Computed Tomography

420 (CBCT) Photographs. Diagnostics (Basel, Switzerland). Diagnostics (Basel), 11(5).

421 Borciani, G., Montalbano, G., Baldini, N., Cerqueni, G., Vitale-Brovarone, C. \& Ciapetti, G.

422 (2020) Co-culture systems of osteoblasts and osteoclasts: Simulating in vitro bone remodeling in 423 regenerative approaches. Acta Biomaterialia. Elsevier, 108, 22-45.

424 Borys, J., Maciejczyk, M., Antonowicz, B., Krętowski, A., Waszkiel, D., Bortnik, P.,

425 Czarniecka-Bargłowska, K., Kocisz, M., Szulimowska, J., Czajkowski, M., Waszkiewicz, N. \&

426 Zalewska, A. (2018) Exposure to Ti4A14V titanium alloy leads to redox abnormalities, oxidative 427 stress, and oxidative damage in patients treated for mandible fractures. Oxidative Medicine and 428 Cellular Longevity, 2018.

429 Carey, JJ, Licata, AA, Delaney, M. (2006) Biochemical markers of bone turnover. Clinic Rev 430 Bone Miner Metab., 4, 197-212.

431 El-Shenawy, N. S., Mohsen, Q. \& Fadl-Allah, S. A. (2012) Oxidative stress and antioxidant 432 responses of liver and kidney tissue after implantation of titanium or titanium oxide coated plate 433 in rat tibiae. Journal of Materials Science: Materials in Medicine, 23(7), 1763-1774.

434 Gomes, L. D. C. R., Horta, K. O. C., Gandini, L. G., Gonçalves, M. \& Gonçalves, J. R. (2013)

435 Photographic assessment of cephalometric measurements. The Angle orthodontist. Angle Orthod, 436 83(6), 1049-1058.

437 Guarnieri, R., Miccoli, G., Reda, R., Mazzoni, A., Di Nardo, D. \& Testarelli, L. (2021) Sulcus 438 fluid volume, IL-6, and Il-1b concentrations in periodontal and peri-implant tissues comparing 
439

440

441

442

443

444

445

446

447

448

449

450

451

452

453

454

455

456

457

458

459

460

461

machined and laser-microtextured collar/abutment surfaces during 12 weeks of healing: A splitmouth RCT. Clinical oral implants research. Clin Oral Implants Res.

Hans, M. G., Martin Palomo, J. \& Valiathan, M. (2015) History of imaging in orthodontics from

Broadbent to cone-beam computed tomography. American Journal of Orthodontics and

Dentofacial Orthopedics. Mosby Inc., 148(6), 914-921.

Hu, X. F., Wang, L., Xiang, G., Lei, W. \& Feng, Y. F. (2018) Angiogenesis impairment by the

NADPH oxidase-triggered oxidative stress at the bone-implant interface: Critical mechanisms

and therapeutic targets for implant failure under hyperglycemic conditions in diabetes. Acta

Biomaterialia. Acta Materialia Inc., 73, 470-487.

Huang, J., Li, R., Yang, J., Cai, M., Lee, Y., Wang, A., Cheng, B. \& Wang, Y. (2021)

Bioadaptation of implants to In vitro and In vivo oxidative stress pathological conditions via nanotopography-induced FoxO1 signaling pathways to enhance Osteoimmunal regeneration.

Bioactive Materials. KeAi Communications Co., Ltd, 6(10), 3164-3176.

IR, G., BF, B., RO, O., L, B., J, P. \& GR, M. (1990) Oxygen-derived free radicals stimulate osteoclastic bone resorption in rodent bone in vitro and in vivo. The Journal of clinical investigation. J Clin Invest, 85(3), 632-639.

Kanczler, J. M. \& Oreffo, R. O. C. (2008) Osteogenesis and angiogenesis: The potential for engineering bone. European Cells and Materials. AO Research Institute Davos, 100-114.

Kitai, N., Murabayashi, M., Sugimoto, H., Fujiwara, A., Tome, W. \& Katsumata, A. (2017)

Accuracy and head positioning effects on measurements of anterior tooth length using 3dimensional and conventional dental panoramic radiography. American journal of orthodontics and dentofacial orthopedics : official publication of the American Association of Orthodontists, its constituent societies, and the American Board of Orthodontics. Am J Orthod Dentofacial 
462 Orthop, 151(3), 607-615.

463 Lee, S., Lee, J., Byun, H., Kim, S. jeong, Joo, J., Park, H. H. \& shin, H. (2021) Evaluation of the 464 anti-oxidative and ROS scavenging properties of biomaterials coated with epigallocatechin 465 gallate for tissue engineering. Acta Biomaterialia. Acta Materialia Inc, 124, 166-178.

466 Lee, Y. H., Bhattarai, G., Park, I. S., Kim, G. R., Kim, G. E., Lee, M. H. \& Yi, H. K. (2013)

467 Bone regeneration around $\mathrm{N}$-acetyl cysteine-loaded nanotube titanium dental implant in rat 468 mandible. Biomaterials. Elsevier Ltd, 34(38), 10199-10208.

469 Liu, W. F., Ma, M., Bratlie, K. M., Dang, T. T., Langer, R. \& Anderson, D. G. (2011) Real-time 470 in vivo detection of biomaterial-induced reactive oxygen species. Biomaterials. NIH Public 471 Access, 32(7), 1796.

472 Long, H. A., French, D. P. \& Brooks, J. M. (no date) Optimising the value of the critical 473 appraisal skills programme (CASP) tool for quality appraisal in qualitative evidence synthesis.

474 Ludlow, J. B., Laster, W. S., See, M., Bailey, L. T. J. \& Hershey, H. G. (2007) Accuracy of 475 measurements of mandibular anatomy in cone beam computed tomography images. Oral 476 surgery, oral medicine, oral pathology, oral radiology, and endodontics. Oral Surg Oral Med 477 Oral Pathol Oral Radiol Endod, 103(4), 534-542.

478 Mariarosaria, B., D’Amato, S., Lama, S., Bitti, G., Salvatore, D., Ravagnan, G., Angelo, I. \& 479 Stiuso, P. (2017) Oxidative Stress Evaluation During Perimplantar Bone Resorption in 480 Immediate Post-Extractive Implant. Oral health and dental management, 16.

481 McHugh, M. L. (2012) Interrater reliability: the kappa statistic. Biochemia Medica. Croatian 482 Society for Medical Biochemistry and Laboratory Medicine, 22(3), 276. Available at: 483 /pmc/articles/PMC3900052/ (Accessed: 4 September 2021).

484 Mehta, P., Sagarkar, R. M. \& Mathew, S. (2017) Photographic Assessment of Cephalometric 
485 Measurements in Skeletal Class II Cases: A Comparative Study. Journal of clinical and

486 diagnostic research : JCDR. J Clin Diagn Res, 11(6), ZC60-ZC64.

487 Mijiritsky, E., Ferroni, L., Gardin, C., Peleg, O., Gultekin, A., Saglanmak, A., Delogu, L. G., 488 Mitrecic, D., Piattelli, A., Tatullo, M. \& Zavan, B. (2019) Presence of ROS in Inflammatory 489 Environment of Peri-Implantitis Tissue: In Vitro and In Vivo Human Evidence. Journal of 490 Clinical Medicine, 9(1), 38.

491 Mizuno, S. \& Glowacki, J. (2000) Dynamics of Bone and Cartilage Metabolism. M.J. Seibel, 492 S.R. Robbins, J.P. Bilezikian (eds.), Academic Press, San Diego, CA, U.S.A., 1999. Journal of 493 Bone and Mineral Research. Wiley, 15(10), 2058-2059.

494 Mouthuy, P. A., Snelling, S. J. B., Dakin, S. G., Milković, L., Gašparović, A. Č., Carr, A. J. \& 495 Žarković, N. (2016) Biocompatibility of implantable materials: An oxidative stress viewpoint. 496 Biomaterials, 109, 55-68.

497 Niska, K., Pyszka, K., Tukaj, C., Wozniak, M., Radomski, M. W. \& Inkielewicz-Stepniak, I. 498 (2015) Titanium dioxide nanoparticles enhance production of superoxide anion and alter the 499 antioxidant system in human osteoblast cells. International Journal of Nanomedicine, 10, 10955001107.

501 Nucera, R., Lo Giudice, A., Bellocchio, M., Spinuzza, P., Caprioglio, A. \& Cordasco, G. (2017)

502 Diagnostic concordance between skeletal cephalometrics, radiograph-based soft-tissue 503 cephalometrics, and photograph-based soft-tissue cephalometrics. European journal of 504 orthodontics. Eur J Orthod, 39(4), 352-357.

505 Pietropaoli, D., Ortu, E., Severino, M., Ciarrocchi, I., Gatto, R. \& Monaco, A. (2013) Glycation 506 and oxidative stress in the failure of dental implants: A case series. BMC Research Notes. BMC 507 Research Notes, 6(1), 1. 
508 Riddle, R. C., Khatri, R., Schipani, E. \& Clemens, T. L. (2009) Role of hypoxia-inducible factor-

$5091 \alpha$ in angiogenic-osteogenic coupling. Journal of Molecular Medicine. J Mol Med (Berl), 583-

$510 \quad 590$.

511 Rooney, A. (2015) Extending a Risk-of-Bias Approach to Address In Vitro. National Toxicology

512 Program Office of Health Assessment and Translation.

513 Santos, M. I. \& Reis, R. L. (2010) Vascularization in bone tissue engineering: Physiology,

514 current strategies, major hurdles and future challenges. Macromolecular Bioscience. Macromol

515 Biosci, 12-27.

516 Sayed, M. E., Mugri, M. H., Almasri, M. A., Al-Ahmari, M. M., Bhandi, S., Madapusi, T. B.,

517 Varadarajan, S., Raj, A. T., Reda, R., Testarelli, L. \& Patil, S. (2021) Role of Stem Cells in

518 Augmenting Dental Implant Osseointegration: A Systematic Review.

519 Shen, X., Yu, Y., Ma, P., Luo, Z., Hu, Y., Li, M., He, Y., Zhang, Y., Peng, Z., Song, G. \& Cai,

520 K. (2019) Titania nanotubes promote osteogenesis via mediating crosstalk between macrophages

521 and MSCs under oxidative stress. Colloids and Surfaces B: Biointerfaces, 180(April), 39-48.

522 Srinivas, U. S., Tan, B. W. Q., Vellayappan, B. A. \& Jeyasekharan, A. D. (2019) ROS and the

523 DNA damage response in cancer. Redox Biology. Elsevier, 25, 101084.

524 Sterne, J. A. C., Savović, J., Page, M. J., Elbers, R. G., Blencowe, N. S., Boutron, I., Cates, C. J.,

525 Cheng, H.-Y., Corbett, M. S., Eldridge, S. M., Emberson, J. R., Hernán, M. A., Hopewell, S.,

526 Hróbjartsson, A., Junqueira, D. R., Jüni, P., Kirkham, J. J., Lasserson, T., Li, T., McAleenan, A.,

527 Reeves, B. C., Shepperd, S., Shrier, I., Stewart, L. A., Tilling, K., White, I. R., Whiting, P. F. \&

528 Higgins, J. P. T. (2019) RoB 2: a revised tool for assessing risk of bias in randomised trials.

529 BMJ. British Medical Journal Publishing Group, 366.

530 Wauquier, F., Leotoing, L., Coxam, V., Guicheux, J. \& Wittrant, Y. (2009) Oxidative stress in 
531 bone remodelling and disease. Trends in Molecular Medicine. Elsevier Current Trends, 15(10), $532468-477$.

533 XC, B., D, L., AL, L., ZM, Z., XM, L., ZP, Z., WS, Z., BL, C. \& SQ, L. (2005) Reactive oxygen

534 species stimulates receptor activator of NF-kappaB ligand expression in osteoblast. The Journal 535 of biological chemistry. J Biol Chem, 280(17), 17497-17506.

536 Xie, H., Guan, A., Liu, W. \& Wu, J. (2014) Study on potential toxic of titanium oxide 537 nanoparticles on osteoblasts. BTAIJ, 10(16), 9204-9210.

538 Y, Z., H, Y., M, G., J, Z., Q, X. \& L, Z. (2013) Reactive oxygen species in vascular formation 539 and development. Oxidative medicine and cellular longevity. Oxid Med Cell Longev, 2013.

540 Yanez, M., Blanchette, J. \& Jabbarzadeh, E. (2017) Modulation of Inflammatory Response to 541 Implanted Biomaterials Using Natural Compounds. Current Pharmaceutical Design. Bentham 542 Science Publishers Ltd., 23(41), 6347-6357.

543 Yang, J., Zhang, H., Man Chan, S., Li, R., Wu, Y., Cai, M., Wang, A. \& Wang, Y. (2020) Tio2 544 nanotubes alleviate diabetes-induced osteogenetic inhibition. International Journal of 545 Nanomedicine, 15, 3523-3537.

546 Yin, Y., Tang, Q., Xie, M., Hu, L. \& Chen, L. (2021) Insights into the mechanism of vascular 547 endothelial cells on bone biology. Bioscience Reports. Portland Press Ltd, 41(1).

548 Yu, Y., Shen, X., Luo, Z., Hu, Y., Li, M., Ma, P., Ran, Q., Dai, L., He, Y. \& Cai, K. (2018)

549 Osteogenesis potential of different titania nanotubes in oxidative stress microenvironment.

550 Biomaterials, 167, 44-57.

551 Zeng, J.-H., Liu, S.-W., Xiong, L., Qiu, P., Ding, L.-H., Xiong, S.-L., Li, J.-T., Liao, X.-G. \&

552 Tang, Z.-M. (2018) Scaffolds for the repair of bone defects in clinical studies: a systematic 553 review. Journal of Orthopaedic Surgery and Research. BioMed Central, 13(1). 
554 Zhang, Y., Yu, W., Jiang, X., Lv, K., Sun, S. \& Zhang, F. (2011) Analysis of the cytotoxicity of

555 differentially sized titanium dioxide nanoparticles in murine MC3T3-E1 preosteoblasts. Journal 556 of Materials Science: Materials in Medicine, 22(8), 1933-1945.

\section{7}

558

Alhammadi, M. S., Al-Mashraqi, A. A., Alnami, R. H., Ashqar, N. M., Alamir, O. H., Halboub,

E., Reda, R., Testarelli, L. \& Patil, S. (2021) Accuracy and Reproducibility of Facial

Measurements of Digital Photographs and Wrapped Cone Beam Computed Tomography

(CBCT) Photographs. Diagnostics (Basel, Switzerland). Diagnostics (Basel), 11(5).

562

Borciani, G., Montalbano, G., Baldini, N., Cerqueni, G., Vitale-Brovarone, C. \& Ciapetti, G.

(2020) Co-culture systems of osteoblasts and osteoclasts: Simulating in vitro bone remodeling in regenerative approaches. Acta Biomaterialia. Elsevier, 108, 22-45.

Borys, J., Maciejczyk, M., Antonowicz, B., Krętowski, A., Waszkiel, D., Bortnik, P.,

Czarniecka-Bargłowska, K., Kocisz, M., Szulimowska, J., Czajkowski, M., Waszkiewicz, N. \&

Zalewska, A. (2018) Exposure to Ti4A14V titanium alloy leads to redox abnormalities, oxidative stress, and oxidative damage in patients treated for mandible fractures. Oxidative Medicine and

569

570

571

572

573

574

575

576

Cellular Longevity, 2018.

Carey, JJ, Licata, AA, Delaney, M. (2006) Biochemical markers of bone turnover. Clinic Rev Bone Miner Metab., 4, 197-212.

El-Shenawy, N. S., Mohsen, Q. \& Fadl-Allah, S. A. (2012) Oxidative stress and antioxidant responses of liver and kidney tissue after implantation of titanium or titanium oxide coated plate in rat tibiae. Journal of Materials Science: Materials in Medicine, 23(7), 1763-1774.

Gomes, L. D. C. R., Horta, K. O. C., Gandini, L. G., Gonçalves, M. \& Gonçalves, J. R. (2013) Photographic assessment of cephalometric measurements. The Angle orthodontist. Angle Orthod, 
577 83(6), 1049-1058.

578 Guarnieri, R., Miccoli, G., Reda, R., Mazzoni, A., Di Nardo, D. \& Testarelli, L. (2021) Sulcus

579 fluid volume, IL-6, and Il-1b concentrations in periodontal and peri-implant tissues comparing

580 machined and laser-microtextured collar/abutment surfaces during 12 weeks of healing: A split-

581 mouth RCT. Clinical oral implants research. Clin Oral Implants Res.

582 Hans, M. G., Martin Palomo, J. \& Valiathan, M. (2015) History of imaging in orthodontics from

583 Broadbent to cone-beam computed tomography. American Journal of Orthodontics and

584 Dentofacial Orthopedics. Mosby Inc., 148(6), 914-921.

585 Hu, X. F., Wang, L., Xiang, G., Lei, W. \& Feng, Y. F. (2018) Angiogenesis impairment by the

586 NADPH oxidase-triggered oxidative stress at the bone-implant interface: Critical mechanisms

587 and therapeutic targets for implant failure under hyperglycemic conditions in diabetes. Acta

588 Biomaterialia. Acta Materialia Inc., 73, 470-487.

589 Huang, J., Li, R., Yang, J., Cai, M., Lee, Y., Wang, A., Cheng, B. \& Wang, Y. (2021)

590 Bioadaptation of implants to In vitro and In vivo oxidative stress pathological conditions via

591 nanotopography-induced FoxO1 signaling pathways to enhance Osteoimmunal regeneration.

592 Bioactive Materials. KeAi Communications Co., Ltd, 6(10), 3164-3176.

593 IR, G., BF, B., RO, O., L, B., J, P. \& GR, M. (1990) Oxygen-derived free radicals stimulate

594 osteoclastic bone resorption in rodent bone in vitro and in vivo. The Journal of clinical

595 investigation. J Clin Invest, 85(3), 632-639.

596 Kanczler, J. M. \& Oreffo, R. O. C. (2008) Osteogenesis and angiogenesis: The potential for

597 engineering bone. European Cells and Materials. AO Research Institute Davos, 100-114.

598 Kitai, N., Murabayashi, M., Sugimoto, H., Fujiwara, A., Tome, W. \& Katsumata, A. (2017)

599 Accuracy and head positioning effects on measurements of anterior tooth length using 3- 
600 dimensional and conventional dental panoramic radiography. American journal of orthodontics

601 and dentofacial orthopedics : official publication of the American Association of Orthodontists,

602 its constituent societies, and the American Board of Orthodontics. Am J Orthod Dentofacial

603 Orthop, 151(3), 607-615.

604 Lee, S., Lee, J., Byun, H., Kim, S. jeong, Joo, J., Park, H. H. \& shin, H. (2021) Evaluation of the

605 anti-oxidative and ROS scavenging properties of biomaterials coated with epigallocatechin

606 gallate for tissue engineering. Acta Biomaterialia. Acta Materialia Inc, 124, 166-178.

607 Lee, Y. H., Bhattarai, G., Park, I. S., Kim, G. R., Kim, G. E., Lee, M. H. \& Yi, H. K. (2013)

608 Bone regeneration around $\mathrm{N}$-acetyl cysteine-loaded nanotube titanium dental implant in rat

609 mandible. Biomaterials. Elsevier Ltd, 34(38), 10199-10208.

610 Liu, W. F., Ma, M., Bratlie, K. M., Dang, T. T., Langer, R. \& Anderson, D. G. (2011) Real-time

611 in vivo detection of biomaterial-induced reactive oxygen species. Biomaterials. NIH Public

612 Access, 32(7), 1796.

613 Long, H. A., French, D. P. \& Brooks, J. M. (no date) Optimising the value of the critical

614 appraisal skills programme (CASP) tool for quality appraisal in qualitative evidence synthesis.

615 Ludlow, J. B., Laster, W. S., See, M., Bailey, L. T. J. \& Hershey, H. G. (2007) Accuracy of

616 measurements of mandibular anatomy in cone beam computed tomography images. Oral

617 surgery, oral medicine, oral pathology, oral radiology, and endodontics. Oral Surg Oral Med

618 Oral Pathol Oral Radiol Endod, 103(4), 534-542.

619 Mariarosaria, B., D’Amato, S., Lama, S., Bitti, G., Salvatore, D., Ravagnan, G., Angelo, I. \&

620 Stiuso, P. (2017) Oxidative Stress Evaluation During Perimplantar Bone Resorption in

621 Immediate Post-Extractive Implant. Oral health and dental management, 16.

622 McHugh, M. L. (2012) Interrater reliability: the kappa statistic. Biochemia Medica. Croatian 
623 Society for Medical Biochemistry and Laboratory Medicine, 22(3), 276. Available at:

624 /pmc/articles/PMC3900052/ (Accessed: 4 September 2021).

625 Mehta, P., Sagarkar, R. M. \& Mathew, S. (2017) Photographic Assessment of Cephalometric

626 Measurements in Skeletal Class II Cases: A Comparative Study. Journal of clinical and

627 diagnostic research : JCDR. J Clin Diagn Res, 11(6), ZC60-ZC64.

628 Mijiritsky, E., Ferroni, L., Gardin, C., Peleg, O., Gultekin, A., Saglanmak, A., Delogu, L. G.,

629 Mitrecic, D., Piattelli, A., Tatullo, M. \& Zavan, B. (2019) Presence of ROS in Inflammatory

630 Environment of Peri-Implantitis Tissue: In Vitro and In Vivo Human Evidence. Journal of

631 Clinical Medicine, 9(1), 38.

632 Mizuno, S. \& Glowacki, J. (2000) Dynamics of Bone and Cartilage Metabolism. M.J. Seibel,

633 S.R. Robbins, J.P. Bilezikian (eds.), Academic Press, San Diego, CA, U.S.A., 1999. Journal of

634 Bone and Mineral Research. Wiley, 15(10), 2058-2059.

635 Mouthuy, P. A., Snelling, S. J. B., Dakin, S. G., Milković, L., Gašparović, A. Č., Carr, A. J. \&

636 Žarković, N. (2016) Biocompatibility of implantable materials: An oxidative stress viewpoint.

637 Biomaterials, 109, 55-68.

638 Niska, K., Pyszka, K., Tukaj, C., Wozniak, M., Radomski, M. W. \& Inkielewicz-Stepniak, I.

639 (2015) Titanium dioxide nanoparticles enhance production of superoxide anion and alter the

640 antioxidant system in human osteoblast cells. International Journal of Nanomedicine, 10, 1095-

6411107.

642 Nucera, R., Lo Giudice, A., Bellocchio, M., Spinuzza, P., Caprioglio, A. \& Cordasco, G. (2017)

643 Diagnostic concordance between skeletal cephalometrics, radiograph-based soft-tissue

644 cephalometrics, and photograph-based soft-tissue cephalometrics. European journal of

645 orthodontics. Eur J Orthod, 39(4), 352-357. 
646 Pietropaoli, D., Ortu, E., Severino, M., Ciarrocchi, I., Gatto, R. \& Monaco, A. (2013) Glycation 647 and oxidative stress in the failure of dental implants: A case series. BMC Research Notes. BMC 648 Research Notes, 6(1), 1.

649 Riddle, R. C., Khatri, R., Schipani, E. \& Clemens, T. L. (2009) Role of hypoxia-inducible factor$6501 \alpha$ in angiogenic-osteogenic coupling. Journal of Molecular Medicine. J Mol Med (Berl), 583651590.

652 Rooney, A. (2015) Extending a Risk-of-Bias Approach to Address In Vitro. National Toxicology 653 Program Office of Health Assessment and Translation.

654 Santos, M. I. \& Reis, R. L. (2010) Vascularization in bone tissue engineering: Physiology, 655 current strategies, major hurdles and future challenges. Macromolecular Bioscience. Macromol 656 Biosci, 12-27.

657 Sayed, M. E., Mugri, M. H., Almasri, M. A., Al-Ahmari, M. M., Bhandi, S., Madapusi, T. B., 658 Varadarajan, S., Raj, A. T., Reda, R., Testarelli, L. \& Patil, S. (2021) Role of Stem Cells in 659 Augmenting Dental Implant Osseointegration: A Systematic Review.

660 Shen, X., Yu, Y., Ma, P., Luo, Z., Hu, Y., Li, M., He, Y., Zhang, Y., Peng, Z., Song, G. \& Cai, 661 K. (2019) Titania nanotubes promote osteogenesis via mediating crosstalk between macrophages 662 and MSCs under oxidative stress. Colloids and Surfaces B: Biointerfaces, 180(April), 39-48.

663 Srinivas, U. S., Tan, B. W. Q., Vellayappan, B. A. \& Jeyasekharan, A. D. (2019) ROS and the 664 DNA damage response in cancer. Redox Biology. Elsevier, 25, 101084.

665 Sterne, J. A. C., Savović, J., Page, M. J., Elbers, R. G., Blencowe, N. S., Boutron, I., Cates, C. J., 666 Cheng, H.-Y., Corbett, M. S., Eldridge, S. M., Emberson, J. R., Hernán, M. A., Hopewell, S., 667 Hróbjartsson, A., Junqueira, D. R., Jüni, P., Kirkham, J. J., Lasserson, T., Li, T., McAleenan, A., 668 Reeves, B. C., Shepperd, S., Shrier, I., Stewart, L. A., Tilling, K., White, I. R., Whiting, P. F. \& 
669 Higgins, J. P. T. (2019) RoB 2: a revised tool for assessing risk of bias in randomised trials. $670 B M J$. British Medical Journal Publishing Group, 366.

671 Wauquier, F., Leotoing, L., Coxam, V., Guicheux, J. \& Wittrant, Y. (2009) Oxidative stress in 672 bone remodelling and disease. Trends in Molecular Medicine. Elsevier Current Trends, 15(10), $673468-477$.

674 XC, B., D, L., AL, L., ZM, Z., XM, L., ZP, Z., WS, Z., BL, C. \& SQ, L. (2005) Reactive oxygen 675 species stimulates receptor activator of NF-kappaB ligand expression in osteoblast. The Journal 676 of biological chemistry. J Biol Chem, 280(17), 17497-17506.

677 Xie, H., Guan, A., Liu, W. \& Wu, J. (2014) Study on potential toxic of titanium oxide 678 nanoparticles on osteoblasts. BTAIJ, 10(16), 9204-9210.

679 Y, Z., H, Y., M, G., J, Z., Q, X. \& L, Z. (2013) Reactive oxygen species in vascular formation 680 and development. Oxidative medicine and cellular longevity. Oxid Med Cell Longev, 2013.

681 Yanez, M., Blanchette, J. \& Jabbarzadeh, E. (2017) Modulation of Inflammatory Response to 682 Implanted Biomaterials Using Natural Compounds. Current Pharmaceutical Design. Bentham 683 Science Publishers Ltd., 23(41), 6347-6357.

684 Yang, J., Zhang, H., Man Chan, S., Li, R., Wu, Y., Cai, M., Wang, A. \& Wang, Y. (2020) Tio2 685 nanotubes alleviate diabetes-induced osteogenetic inhibition. International Journal of 686 Nanomedicine, 15, 3523-3537.

687 Yin, Y., Tang, Q., Xie, M., Hu, L. \& Chen, L. (2021) Insights into the mechanism of vascular 688 endothelial cells on bone biology. Bioscience Reports. Portland Press Ltd, 41(1).

689 Yu, Y., Shen, X., Luo, Z., Hu, Y., Li, M., Ma, P., Ran, Q., Dai, L., He, Y. \& Cai, K. (2018)

690 Osteogenesis potential of different titania nanotubes in oxidative stress microenvironment.

691 Biomaterials, 167, 44-57. 
692 Zeng, J.-H., Liu, S.-W., Xiong, L., Qiu, P., Ding, L.-H., Xiong, S.-L., Li, J.-T., Liao, X.-G. \& 693 Tang, Z.-M. (2018) Scaffolds for the repair of bone defects in clinical studies: a systematic 694 review. Journal of Orthopaedic Surgery and Research. BioMed Central, 13(1).

695 Zhang, Y., Yu, W., Jiang, X., Lv, K., Sun, S. \& Zhang, F. (2011) Analysis of the cytotoxicity of 696 differentially sized titanium dioxide nanoparticles in murine MC3T3-E1 preosteoblasts. Journal 697 of Materials Science: Materials in Medicine, 22(8), 1933-1945.

698

699 Alhammadi, M. S., Al-Mashraqi, A. A., Alnami, R. H., Ashqar, N. M., Alamir, O. H., Halboub, 700 E., Reda, R., Testarelli, L. \& Patil, S. (2021) Accuracy and Reproducibility of Facial 701 Measurements of Digital Photographs and Wrapped Cone Beam Computed Tomography 702 (CBCT) Photographs. Diagnostics (Basel, Switzerland). Diagnostics (Basel), 11(5).

703 Borciani, G., Montalbano, G., Baldini, N., Cerqueni, G., Vitale-Brovarone, C. \& Ciapetti, G.

704 (2020) Co-culture systems of osteoblasts and osteoclasts: Simulating in vitro bone remodeling in 705 regenerative approaches. Acta Biomaterialia. Elsevier, 108, 22-45.

706 Borys, J., Maciejczyk, M., Antonowicz, B., Krętowski, A., Waszkiel, D., Bortnik, P.,

707 Czarniecka-Bargłowska, K., Kocisz, M., Szulimowska, J., Czajkowski, M., Waszkiewicz, N. \& 708 Zalewska, A. (2018) Exposure to Ti4A14V titanium alloy leads to redox abnormalities, oxidative 709 stress, and oxidative damage in patients treated for mandible fractures. Oxidative Medicine and 710 Cellular Longevity, 2018.

711 Carey, JJ, Licata, AA, Delaney, M. (2006) Biochemical markers of bone turnover. Clinic Rev 712 Bone Miner Metab., 4, 197-212. El-Shenawy, N. S., Mohsen, Q. \& Fadl-Allah, S. A. (2012) Oxidative stress and antioxidant responses of liver and kidney tissue after implantation of titanium or titanium oxide coated plate 
715 in rat tibiae. Journal of Materials Science: Materials in Medicine, 23(7), 1763-1774.

716 Gomes, L. D. C. R., Horta, K. O. C., Gandini, L. G., Gonçalves, M. \& Gonçalves, J. R. (2013)

717 Photographic assessment of cephalometric measurements. The Angle orthodontist. Angle Orthod, 718 83(6), 1049-1058.

719 Guarnieri, R., Miccoli, G., Reda, R., Mazzoni, A., Di Nardo, D. \& Testarelli, L. (2021) Sulcus

720 fluid volume, IL-6, and Il-1b concentrations in periodontal and peri-implant tissues comparing

721 machined and laser-microtextured collar/abutment surfaces during 12 weeks of healing: A split-

722 mouth RCT. Clinical oral implants research. Clin Oral Implants Res.

723 Hans, M. G., Martin Palomo, J. \& Valiathan, M. (2015) History of imaging in orthodontics from

724 Broadbent to cone-beam computed tomography. American Journal of Orthodontics and

725 Dentofacial Orthopedics. Mosby Inc., 148(6), 914-921.

726 Hu, X. F., Wang, L., Xiang, G., Lei, W. \& Feng, Y. F. (2018) Angiogenesis impairment by the

727 NADPH oxidase-triggered oxidative stress at the bone-implant interface: Critical mechanisms

728 and therapeutic targets for implant failure under hyperglycemic conditions in diabetes. Acta

729 Biomaterialia. Acta Materialia Inc., 73, 470-487.

730 Huang, J., Li, R., Yang, J., Cai, M., Lee, Y., Wang, A., Cheng, B. \& Wang, Y. (2021)

731 Bioadaptation of implants to In vitro and In vivo oxidative stress pathological conditions via

732 nanotopography-induced FoxO1 signaling pathways to enhance Osteoimmunal regeneration.

733 Bioactive Materials. KeAi Communications Co., Ltd, 6(10), 3164-3176.

734 IR, G., BF, B., RO, O., L, B., J, P. \& GR, M. (1990) Oxygen-derived free radicals stimulate 735 osteoclastic bone resorption in rodent bone in vitro and in vivo. The Journal of clinical

736 investigation. J Clin Invest, 85(3), 632-639.

737 Kanczler, J. M. \& Oreffo, R. O. C. (2008) Osteogenesis and angiogenesis: The potential for 
738 engineering bone. European Cells and Materials. AO Research Institute Davos, 100-114.

739 Kitai, N., Murabayashi, M., Sugimoto, H., Fujiwara, A., Tome, W. \& Katsumata, A. (2017)

740 Accuracy and head positioning effects on measurements of anterior tooth length using 3-

741 dimensional and conventional dental panoramic radiography. American journal of orthodontics

742 and dentofacial orthopedics : official publication of the American Association of Orthodontists,

743 its constituent societies, and the American Board of Orthodontics. Am J Orthod Dentofacial

744 Orthop, 151(3), 607-615.

745 Lee, S., Lee, J., Byun, H., Kim, S. jeong, Joo, J., Park, H. H. \& shin, H. (2021) Evaluation of the

746 anti-oxidative and ROS scavenging properties of biomaterials coated with epigallocatechin

747 gallate for tissue engineering. Acta Biomaterialia. Acta Materialia Inc, 124, 166-178.

748 Lee, Y. H., Bhattarai, G., Park, I. S., Kim, G. R., Kim, G. E., Lee, M. H. \& Yi, H. K. (2013)

749 Bone regeneration around $\mathrm{N}$-acetyl cysteine-loaded nanotube titanium dental implant in rat

750 mandible. Biomaterials. Elsevier Ltd, 34(38), 10199-10208.

751 Liu, W. F., Ma, M., Bratlie, K. M., Dang, T. T., Langer, R. \& Anderson, D. G. (2011) Real-time

752 in vivo detection of biomaterial-induced reactive oxygen species. Biomaterials. NIH Public

753 Access, 32(7), 1796.

754 Long, H. A., French, D. P. \& Brooks, J. M. (no date) Optimising the value of the critical

755 appraisal skills programme (CASP) tool for quality appraisal in qualitative evidence synthesis.

756 Ludlow, J. B., Laster, W. S., See, M., Bailey, L. T. J. \& Hershey, H. G. (2007) Accuracy of

757 measurements of mandibular anatomy in cone beam computed tomography images. Oral

758 surgery, oral medicine, oral pathology, oral radiology, and endodontics. Oral Surg Oral Med

759 Oral Pathol Oral Radiol Endod, 103(4), 534-542.

760 Mariarosaria, B., D’Amato, S., Lama, S., Bitti, G., Salvatore, D., Ravagnan, G., Angelo, I. \& 
761 Stiuso, P. (2017) Oxidative Stress Evaluation During Perimplantar Bone Resorption in

762 Immediate Post-Extractive Implant. Oral health and dental management, 16.

763 McHugh, M. L. (2012) Interrater reliability: the kappa statistic. Biochemia Medica. Croatian

764 Society for Medical Biochemistry and Laboratory Medicine, 22(3), 276. Available at:

765 /pmc/articles/PMC3900052/ (Accessed: 4 September 2021).

766 Mehta, P., Sagarkar, R. M. \& Mathew, S. (2017) Photographic Assessment of Cephalometric

767 Measurements in Skeletal Class II Cases: A Comparative Study. Journal of clinical and

768 diagnostic research : JCDR. J Clin Diagn Res, 11(6), ZC60-ZC64.

769 Mijiritsky, E., Ferroni, L., Gardin, C., Peleg, O., Gultekin, A., Saglanmak, A., Delogu, L. G.,

770 Mitrecic, D., Piattelli, A., Tatullo, M. \& Zavan, B. (2019) Presence of ROS in Inflammatory

771 Environment of Peri-Implantitis Tissue: In Vitro and In Vivo Human Evidence. Journal of

772 Clinical Medicine, 9(1), 38.

773 Mizuno, S. \& Glowacki, J. (2000) Dynamics of Bone and Cartilage Metabolism. M.J. Seibel,

774 S.R. Robbins, J.P. Bilezikian (eds.), Academic Press, San Diego, CA, U.S.A., 1999. Journal of

775 Bone and Mineral Research. Wiley, 15(10), 2058-2059.

776 Mouthuy, P. A., Snelling, S. J. B., Dakin, S. G., Milković, L., Gašparović, A. Č., Carr, A. J. \&

777 Žarković, N. (2016) Biocompatibility of implantable materials: An oxidative stress viewpoint.

778 Biomaterials, 109, 55-68.

779 Niska, K., Pyszka, K., Tukaj, C., Wozniak, M., Radomski, M. W. \& Inkielewicz-Stepniak, I.

780 (2015) Titanium dioxide nanoparticles enhance production of superoxide anion and alter the

781 antioxidant system in human osteoblast cells. International Journal of Nanomedicine, 10, 1095-

7821107.

783 Nucera, R., Lo Giudice, A., Bellocchio, M., Spinuzza, P., Caprioglio, A. \& Cordasco, G. (2017) 
784 Diagnostic concordance between skeletal cephalometrics, radiograph-based soft-tissue 785 cephalometrics, and photograph-based soft-tissue cephalometrics. European journal of 786 orthodontics. Eur J Orthod, 39(4), 352-357.

787 Pietropaoli, D., Ortu, E., Severino, M., Ciarrocchi, I., Gatto, R. \& Monaco, A. (2013) Glycation 788 and oxidative stress in the failure of dental implants: A case series. BMC Research Notes. BMC 789 Research Notes, 6(1), 1.

790 Riddle, R. C., Khatri, R., Schipani, E. \& Clemens, T. L. (2009) Role of hypoxia-inducible factor$7911 \alpha$ in angiogenic-osteogenic coupling. Journal of Molecular Medicine. J Mol Med (Berl), 583792590.

793 Rooney, A. (2015) Extending a Risk-of-Bias Approach to Address In Vitro. National Toxicology 794 Program Office of Health Assessment and Translation.

795 Santos, M. I. \& Reis, R. L. (2010) Vascularization in bone tissue engineering: Physiology, 796 current strategies, major hurdles and future challenges. Macromolecular Bioscience. Macromol 797 Biosci, 12-27.

798 Sayed, M. E., Mugri, M. H., Almasri, M. A., Al-Ahmari, M. M., Bhandi, S., Madapusi, T. B., 799 Varadarajan, S., Raj, A. T., Reda, R., Testarelli, L. \& Patil, S. (2021) Role of Stem Cells in 800 Augmenting Dental Implant Osseointegration: A Systematic Review.

801 Shen, X., Yu, Y., Ma, P., Luo, Z., Hu, Y., Li, M., He, Y., Zhang, Y., Peng, Z., Song, G. \& Cai, 802 K. (2019) Titania nanotubes promote osteogenesis via mediating crosstalk between macrophages 803 and MSCs under oxidative stress. Colloids and Surfaces B: Biointerfaces, 180(April), 39-48.

804 Srinivas, U. S., Tan, B. W. Q., Vellayappan, B. A. \& Jeyasekharan, A. D. (2019) ROS and the 805 DNA damage response in cancer. Redox Biology. Elsevier, 25, 101084.

806 Sterne, J. A. C., Savović, J., Page, M. J., Elbers, R. G., Blencowe, N. S., Boutron, I., Cates, C. J., 
807 Cheng, H.-Y., Corbett, M. S., Eldridge, S. M., Emberson, J. R., Hernán, M. A., Hopewell, S., 808 Hróbjartsson, A., Junqueira, D. R., Jüni, P., Kirkham, J. J., Lasserson, T., Li, T., McAleenan, A.,

809 Reeves, B. C., Shepperd, S., Shrier, I., Stewart, L. A., Tilling, K., White, I. R., Whiting, P. F. \& 810 Higgins, J. P. T. (2019) RoB 2: a revised tool for assessing risk of bias in randomised trials.

811 BMJ. British Medical Journal Publishing Group, 366.

812 Wauquier, F., Leotoing, L., Coxam, V., Guicheux, J. \& Wittrant, Y. (2009) Oxidative stress in 813 bone remodelling and disease. Trends in Molecular Medicine. Elsevier Current Trends, 15(10), $814 \quad 468-477$.

815 XC, B., D, L., AL, L., ZM, Z., XM, L., ZP, Z., WS, Z., BL, C. \& SQ, L. (2005) Reactive oxygen 816 species stimulates receptor activator of NF-kappaB ligand expression in osteoblast. The Journal 817 of biological chemistry. J Biol Chem, 280(17), 17497-17506.

818 Xie, H., Guan, A., Liu, W. \& Wu, J. (2014) Study on potential toxic of titanium oxide 819 nanoparticles on osteoblasts. BTAIJ, 10(16), 9204-9210.

820 Y, Z., H, Y., M, G., J, Z., Q, X. \& L, Z. (2013) Reactive oxygen species in vascular formation 821 and development. Oxidative medicine and cellular longevity. Oxid Med Cell Longev, 2013.

822 Yanez, M., Blanchette, J. \& Jabbarzadeh, E. (2017) Modulation of Inflammatory Response to 823 Implanted Biomaterials Using Natural Compounds. Current Pharmaceutical Design. Bentham 824 Science Publishers Ltd., 23(41), 6347-6357.

825 Yang, J., Zhang, H., Man Chan, S., Li, R., Wu, Y., Cai, M., Wang, A. \& Wang, Y. (2020) Tio2 826 nanotubes alleviate diabetes-induced osteogenetic inhibition. International Journal of 827 Nanomedicine, 15, 3523-3537.

828 Yin, Y., Tang, Q., Xie, M., Hu, L. \& Chen, L. (2021) Insights into the mechanism of vascular 829 endothelial cells on bone biology. Bioscience Reports. Portland Press Ltd, 41(1). 
830 Yu, Y., Shen, X., Luo, Z., Hu, Y., Li, M., Ma, P., Ran, Q., Dai, L., He, Y. \& Cai, K. (2018)

831 Osteogenesis potential of different titania nanotubes in oxidative stress microenvironment.

832 Biomaterials, 167, 44-57.

833 Zeng, J.-H., Liu, S.-W., Xiong, L., Qiu, P., Ding, L.-H., Xiong, S.-L., Li, J.-T., Liao, X.-G. \&

834 Tang, Z.-M. (2018) Scaffolds for the repair of bone defects in clinical studies: a systematic

835 review. Journal of Orthopaedic Surgery and Research. BioMed Central, 13(1).

836 Zhang, Y., Yu, W., Jiang, X., Lv, K., Sun, S. \& Zhang, F. (2011) Analysis of the cytotoxicity of

837 differentially sized titanium dioxide nanoparticles in murine MC3T3-E1 preosteoblasts. Journal

838 of Materials Science: Materials in Medicine, 22(8), 1933-1945.

839

840 Alhammadi, M. S., Al-Mashraqi, A. A., Alnami, R. H., Ashqar, N. M., Alamir, O. H., Halboub, E., Reda,

841 R., Testarelli, L. \& Patil, S. (2021) Accuracy and Reproducibility of Facial Measurements of Digital

842 Photographs and Wrapped Cone Beam Computed Tomography (CBCT) Photographs. Diagnostics (Basel,

843 Switzerland). Diagnostics (Basel), 11(5).

844 Borciani, G., Montalbano, G., Baldini, N., Cerqueni, G., Vitale-Brovarone, C. \& Ciapetti, G. (2020) Co-

845 culture systems of osteoblasts and osteoclasts: Simulating in vitro bone remodeling in regenerative

846 approaches. Acta Biomaterialia. Elsevier, 108, 22-45.

847 Borys, J., Maciejczyk, M., Antonowicz, B., Krętowski, A., Waszkiel, D., Bortnik, P., Czarniecka-

848 Bargłowska, K., Kocisz, M., Szulimowska, J., Czajkowski, M., Waszkiewicz, N. \& Zalewska, A. (2018)

849 Exposure to Ti4A14V titanium alloy leads to redox abnormalities, oxidative stress, and oxidative damage

850 in patients treated for mandible fractures. Oxidative Medicine and Cellular Longevity, 2018.

851 Carey, JJ, Licata, AA, Delaney, M. (2006) Biochemical markers of bone turnover. Clinic Rev Bone Miner

852 Metab., 4, 197-212.

Peer) reviewing PDF | (2021:10:67049:1:2:NEW 4 Jan 2022) 
853

854 855

856

857

858

859

860

861

862

863

864

865

866

867

868

869

870

871

872

873

874

875

876

El-Shenawy, N. S., Mohsen, Q. \& Fadl-Allah, S. A. (2012) Oxidative stress and antioxidant responses of liver and kidney tissue after implantation of titanium or titanium oxide coated plate in rat tibiae. Journal of Materials Science: Materials in Medicine, 23(7), 1763-1774.

Gomes, L. D. C. R., Horta, K. O. C., Gandini, L. G., Gonçalves, M. \& Gonçalves, J. R. (2013)

Photographic assessment of cephalometric measurements. The Angle orthodontist. Angle Orthod, 83(6), 1049-1058.

Guarnieri, R., Miccoli, G., Reda, R., Mazzoni, A., Di Nardo, D. \& Testarelli, L. (2021) Sulcus fluid volume, IL-6, and Il-1b concentrations in periodontal and peri-implant tissues comparing machined and laser-microtextured collar/abutment surfaces during 12 weeks of healing: A split-mouth RCT. Clinical oral implants research. Clin Oral Implants Res.

Hans, M. G., Martin Palomo, J. \& Valiathan, M. (2015) History of imaging in orthodontics from Broadbent to cone-beam computed tomography. American Journal of Orthodontics and Dentofacial Orthopedics. Mosby Inc., 148(6), 914-921.

Hu, X. F., Wang, L., Xiang, G., Lei, W. \& Feng, Y. F. (2018) Angiogenesis impairment by the NADPH oxidase-triggered oxidative stress at the bone-implant interface: Critical mechanisms and therapeutic targets for implant failure under hyperglycemic conditions in diabetes. Acta Biomaterialia. Acta Materialia Inc., 73, 470-487.

Huang, J., Li, R., Yang, J., Cai, M., Lee, Y., Wang, A., Cheng, B. \& Wang, Y. (2021) Bioadaptation of implants to In vitro and In vivo oxidative stress pathological conditions via nanotopography-induced FoxO1 signaling pathways to enhance Osteoimmunal regeneration. Bioactive Materials. KeAi Communications Co., Ltd, 6(10), 3164-3176.

IR, G., BF, B., RO, O., L, B., J, P. \& GR, M. (1990) Oxygen-derived free radicals stimulate osteoclastic bone resorption in rodent bone in vitro and in vivo. The Journal of clinical investigation. J Clin Invest, $\mathbf{8 5}(3), 632-639$. 
877 Kanczler, J. M. \& Oreffo, R. O. C. (2008) Osteogenesis and angiogenesis: The potential for engineering 878 bone. European Cells and Materials. AO Research Institute Davos, 100-114.

879 Kitai, N., Murabayashi, M., Sugimoto, H., Fujiwara, A., Tome, W. \& Katsumata, A. (2017) Accuracy and 880 head positioning effects on measurements of anterior tooth length using 3-dimensional and conventional 881 dental panoramic radiography. American journal of orthodontics and dentofacial orthopedics : official 882 883 publication of the American Association of Orthodontists, its constituent societies, and the American Board of Orthodontics. Am J Orthod Dentofacial Orthop, 151(3), 607-615.

884 885 886
Lee, S., Lee, J., Byun, H., Kim, S. jeong, Joo, J., Park, H. H. \& shin, H. (2021) Evaluation of the antioxidative and ROS scavenging properties of biomaterials coated with epigallocatechin gallate for tissue engineering. Acta Biomaterialia. Acta Materialia Inc, 124, 166-178.

Lee, Y. H., Bhattarai, G., Park, I. S., Kim, G. R., Kim, G. E., Lee, M. H. \& Yi, H. K. (2013) Bone regeneration around $\mathrm{N}$-acetyl cysteine-loaded nanotube titanium dental implant in rat mandible. Biomaterials. Elsevier Ltd, 34(38), 10199-10208.

Liu, W. F., Ma, M., Bratlie, K. M., Dang, T. T., Langer, R. \& Anderson, D. G. (2011) Real-time in vivo detection of biomaterial-induced reactive oxygen species. Biomaterials. NIH Public Access, 32(7), 1796.

Long, H. A., French, D. P. \& Brooks, J. M. (no date) Optimising the value of the critical appraisal skills programme (CASP) tool for quality appraisal in qualitative evidence synthesis.

Ludlow, J. B., Laster, W. S., See, M., Bailey, L. T. J. \& Hershey, H. G. (2007) Accuracy of measurements of mandibular anatomy in cone beam computed tomography images. Oral surgery, oral medicine, oral pathology, oral radiology, and endodontics. Oral Surg Oral Med Oral Pathol Oral Radiol Endod, 103(4), 534-542.

Mariarosaria, B., D’Amato, S., Lama, S., Bitti, G., Salvatore, D., Ravagnan, G., Angelo, I. \& Stiuso, P. (2017) Oxidative Stress Evaluation During Perimplantar Bone Resorption in Immediate Post-Extractive 
900

901

902

903

904

905

906

907

908

909

910

911

912

913

914 915 55-68.

916

917

918

919

920

92

$922 \quad 352-357$.

Implant. Oral health and dental management, 16.

McHugh, M. L. (2012) Interrater reliability: the kappa statistic. Biochemia Medica. Croatian Society for Medical Biochemistry and Laboratory Medicine, 22(3), 276. Available at: /pmc/articles/PMC3900052/ (Accessed: 4 September 2021).

Mehta, P., Sagarkar, R. M. \& Mathew, S. (2017) Photographic Assessment of Cephalometric Measurements in Skeletal Class II Cases: A Comparative Study. Journal of clinical and diagnostic research : JCDR. J Clin Diagn Res, 11(6), ZC60-ZC64.

Mijiritsky, E., Ferroni, L., Gardin, C., Peleg, O., Gultekin, A., Saglanmak, A., Delogu, L. G., Mitrecic, D., Piattelli, A., Tatullo, M. \& Zavan, B. (2019) Presence of ROS in Inflammatory Environment of PeriImplantitis Tissue: In Vitro and In Vivo Human Evidence. Journal of Clinical Medicine, 9(1), 38.

Mizuno, S. \& Glowacki, J. (2000) Dynamics of Bone and Cartilage Metabolism. M.J. Seibel, S.R. Robbins, J.P. Bilezikian (eds.), Academic Press, San Diego, CA, U.S.A., 1999. Journal of Bone and Mineral Research. Wiley, 15(10), 2058-2059.

Mouthuy, P. A., Snelling, S. J. B., Dakin, S. G., Milković, L., Gašparović, A. Č., Carr, A. J. \& Žarković, N. (2016) Biocompatibility of implantable materials: An oxidative stress viewpoint. Biomaterials, 109,

Niska, K., Pyszka, K., Tukaj, C., Wozniak, M., Radomski, M. W. \& Inkielewicz-Stepniak, I. (2015) Titanium dioxide nanoparticles enhance production of superoxide anion and alter the antioxidant system in human osteoblast cells. International Journal of Nanomedicine, 10, 1095-1107.

919 Nucera, R., Lo Giudice, A., Bellocchio, M., Spinuzza, P., Caprioglio, A. \& Cordasco, G. (2017) Diagnostic concordance between skeletal cephalometrics, radiograph-based soft-tissue cephalometrics, and photograph-based soft-tissue cephalometrics. European journal of orthodontics. Eur J Orthod, 39(4),

Peer) reviewing PDF | (2021:10:67049:1:2:NEW 4 Jan 2022) 
923 Pietropaoli, D., Ortu, E., Severino, M., Ciarrocchi, I., Gatto, R. \& Monaco, A. (2013) Glycation and

924 oxidative stress in the failure of dental implants: A case series. BMC Research Notes. BMC Research

925 Notes, 6(1), 1.

926 Riddle, R. C., Khatri, R., Schipani, E. \& Clemens, T. L. (2009) Role of hypoxia-inducible factor-1 $\alpha$ in

927 angiogenic-osteogenic coupling. Journal of Molecular Medicine. J Mol Med (Berl), 583-590.

928 Rooney, A. (2015) Extending a Risk-of-Bias Approach to Address In Vitro. National Toxicology

929 Program Office of Health Assessment and Translation.

930 Santos, M. I. \& Reis, R. L. (2010) Vascularization in bone tissue engineering: Physiology, current

931 strategies, major hurdles and future challenges. Macromolecular Bioscience. Macromol Biosci, 12-27.

932 Sayed, M. E., Mugri, M. H., Almasri, M. A., Al-Ahmari, M. M., Bhandi, S., Madapusi, T. B.,

933 Varadarajan, S., Raj, A. T., Reda, R., Testarelli, L. \& Patil, S. (2021) Role of Stem Cells in Augmenting

934 Dental Implant Osseointegration: A Systematic Review.

935 Shen, X., Yu, Y., Ma, P., Luo, Z., Hu, Y., Li, M., He, Y., Zhang, Y., Peng, Z., Song, G. \& Cai, K. (2019)

936 Titania nanotubes promote osteogenesis via mediating crosstalk between macrophages and MSCs under

937 oxidative stress. Colloids and Surfaces B: Biointerfaces, 180(April), 39-48.

938 Srinivas, U. S., Tan, B. W. Q., Vellayappan, B. A. \& Jeyasekharan, A. D. (2019) ROS and the DNA 939 damage response in cancer. Redox Biology. Elsevier, 25, 101084.

940 Sterne, J. A. C., Savović, J., Page, M. J., Elbers, R. G., Blencowe, N. S., Boutron, I., Cates, C. J., Cheng,

941 H.-Y., Corbett, M. S., Eldridge, S. M., Emberson, J. R., Hernán, M. A., Hopewell, S., Hróbjartsson, A.,

942 Junqueira, D. R., Jüni, P., Kirkham, J. J., Lasserson, T., Li, T., McAleenan, A., Reeves, B. C., Shepperd,

943 S., Shrier, I., Stewart, L. A., Tilling, K., White, I. R., Whiting, P. F. \& Higgins, J. P. T. (2019) RoB 2: a

944 revised tool for assessing risk of bias in randomised trials. BMJ. British Medical Journal Publishing

945 Group, 366.

Peer) reviewing PDF | (2021:10:67049:1:2:NEW 4 Jan 2022) 
946 Wauquier, F., Leotoing, L., Coxam, V., Guicheux, J. \& Wittrant, Y. (2009) Oxidative stress in bone

947 remodelling and disease. Trends in Molecular Medicine. Elsevier Current Trends, 15(10), 468-477.

948 XC, B., D, L., AL, L., ZM, Z., XM, L., ZP, Z., WS, Z., BL, C. \& SQ, L. (2005) Reactive oxygen species

949 stimulates receptor activator of NF-kappaB ligand expression in osteoblast. The Journal of biological

950 chemistry. J Biol Chem, 280(17), 17497-17506.

951 Xie, H., Guan, A., Liu, W. \& Wu, J. (2014) Study on potential toxic of titanium oxide nanoparticles on 952 osteoblasts. BTAIJ, 10(16), 9204-9210.

953 Y, Z., H, Y., M, G., J, Z., Q, X. \& L, Z. (2013) Reactive oxygen species in vascular formation and 954 development. Oxidative medicine and cellular longevity. Oxid Med Cell Longev, 2013.

955 Yanez, M., Blanchette, J. \& Jabbarzadeh, E. (2017) Modulation of Inflammatory Response to Implanted 956 Biomaterials Using Natural Compounds. Current Pharmaceutical Design. Bentham Science Publishers 957 Ltd., 23(41), 6347-6357.

958 Yang, J., Zhang, H., Man Chan, S., Li, R., Wu, Y., Cai, M., Wang, A. \& Wang, Y. (2020) Tio2 nanotubes 959 alleviate diabetes-induced osteogenetic inhibition. International Journal of Nanomedicine, 15, 35239603537.

961 Yin, Y., Tang, Q., Xie, M., Hu, L. \& Chen, L. (2021) Insights into the mechanism of vascular endothelial 962 cells on bone biology. Bioscience Reports. Portland Press Ltd, 41(1).

963 Yu, Y., Shen, X., Luo, Z., Hu, Y., Li, M., Ma, P., Ran, Q., Dai, L., He, Y. \& Cai, K. (2018) Osteogenesis 964 potential of different titania nanotubes in oxidative stress microenvironment. Biomaterials, 167, 44-57.

965 Zeng, J.-H., Liu, S.-W., Xiong, L., Qiu, P., Ding, L.-H., Xiong, S.-L., Li, J.-T., Liao, X.-G. \& Tang, Z.-

966 M. (2018) Scaffolds for the repair of bone defects in clinical studies: a systematic review. Journal of 967 Orthopaedic Surgery and Research. BioMed Central, 13(1).

968 Zhang, Y., Yu, W., Jiang, X., Lv, K., Sun, S. \& Zhang, F. (2011) Analysis of the cytotoxicity of 
969 differentially sized titanium dioxide nanoparticles in murine MC3T3-E1 preosteoblasts. Journal of 970 Materials Science: Materials in Medicine, 22(8), 1933-1945.

971 


\section{Table Caption:}

973 Table 1. A descriptive summary of the findings are tabulated based on the focused question.

974 Table 2. Critical Appraisal Skills Program Checklist for Quality Assessment of Observational 975 Studies (CASP) (Long et al., 2020). 
976 Figure Caption:

977 Figure 1. ROS modulation of signaling pathways in bone cells. ROS promote bone loss by inhibiting 978 osteoblast differentiation and enhancing osteoclastogenesis. ROS induced bone resorption occurs directly 979 or indirectly (increased RANKL expression) through the modulation of kinases and transcription factor 980 activities in both osteoclasts and osteoblasts.

981

982 Figure 2. Summary of the systematic review workflow using PRISMA chart.

983 Figure 3. Risk bias assessment for Randomized clinical trail.

984 Figure 4. Risk Bias assessment for non-randomized clinical trials.

985 Figure 5. Risk of Bias assessment of in vitro studies.

986 Figure 6. Schematic figure of the link between dental implant surface, presence of particles release, 987 oxidative stress generation, antioxidant production, and their effects on bone remodeling markers. 


\section{Figure 1}

Figure 1.

ROS modulation of signaling pathways in bone cells. ROS promote bone loss by inhibiting osteoblast differentiation and enhancing osteoclastogenesis. ROS induced bone resorption occurs directly or indirectly (increased RANKL expression) through the modulation of kinases and transcription factor activities in both osteoclasts and osteoblasts. 


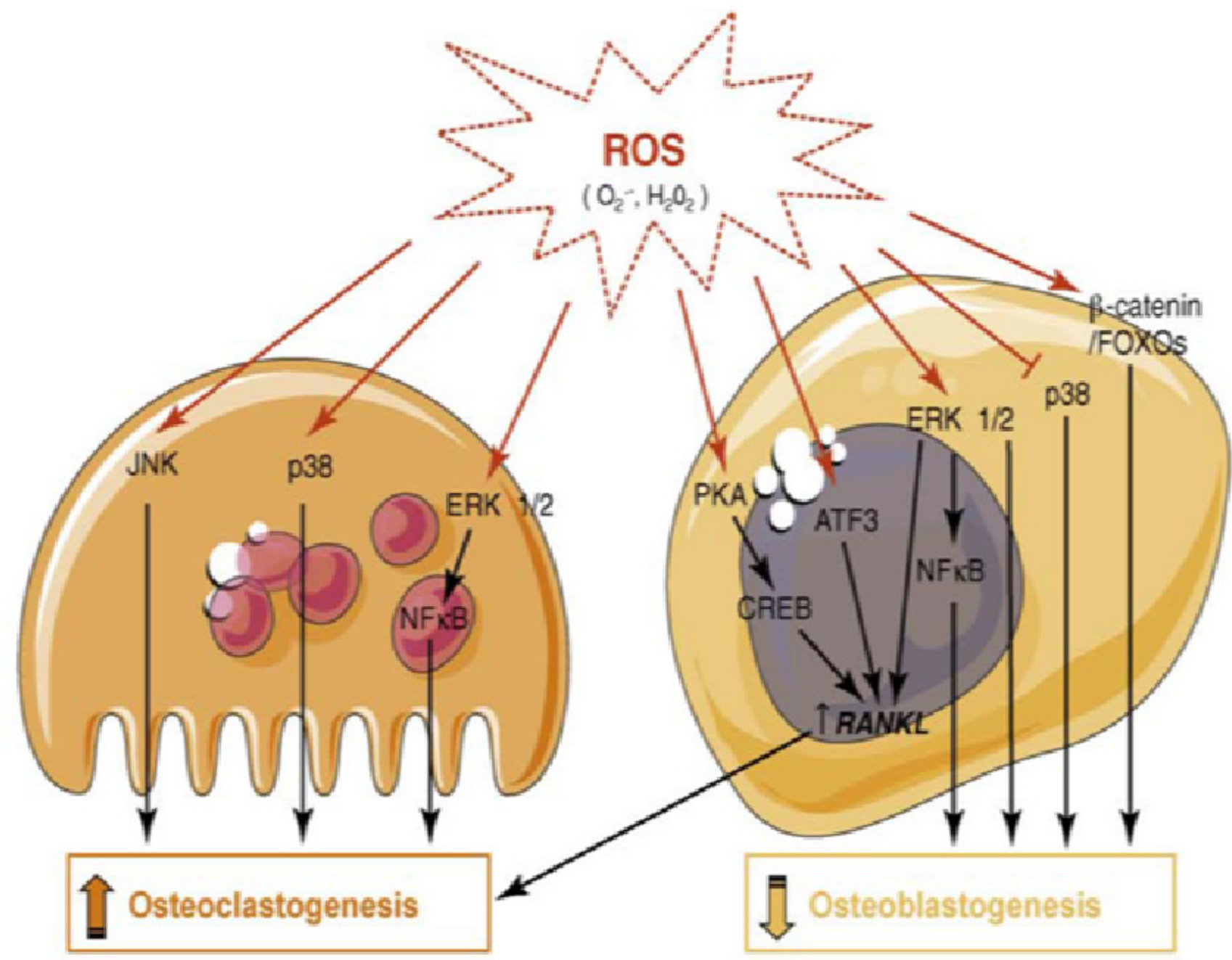


Figure 2

Figure 2.

Summary of the systematic review workflow using PRISMA chart.

Records identified through database searching (PubMed, Science Direct, Scopus and Medline databases)

$(n=750)$
Additional records identified

through other sources

$(n=5)$

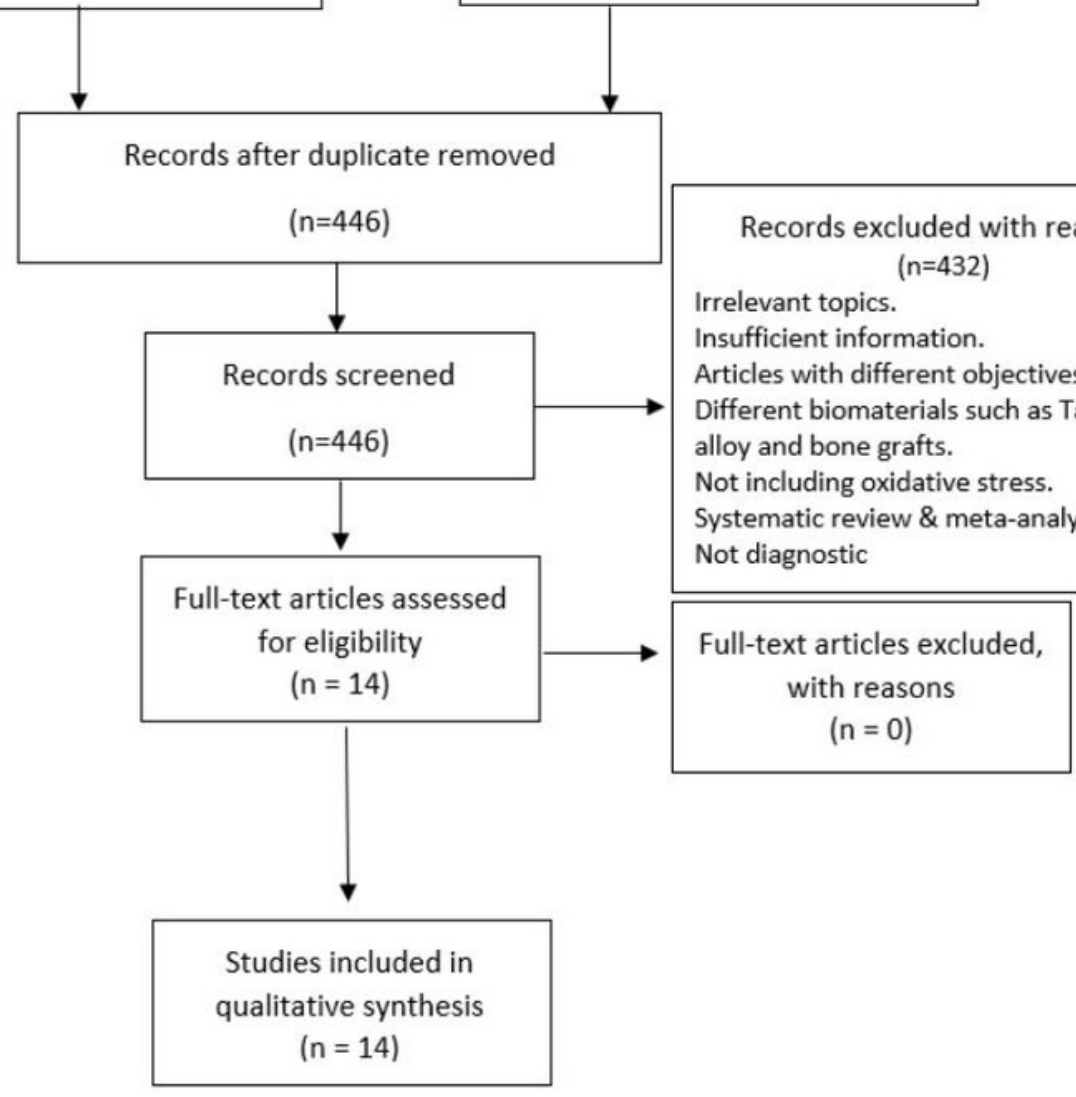


Figure 3

Figure 3.

Risk bias assessment for Randomized clinical trail.

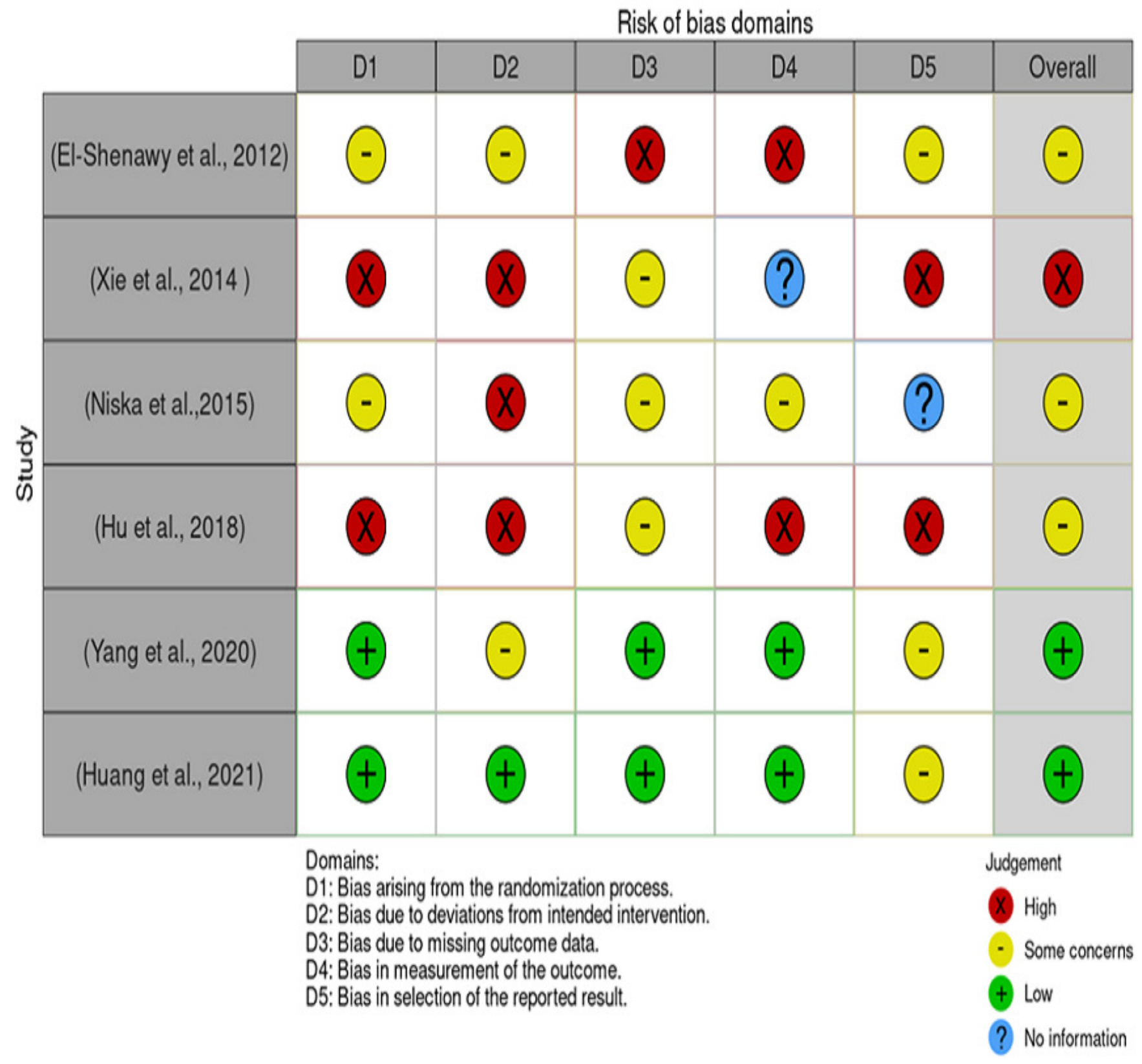




\section{Figure 4}

Figure 4.

Risk Bias assessment for non-randomized clinical trials.

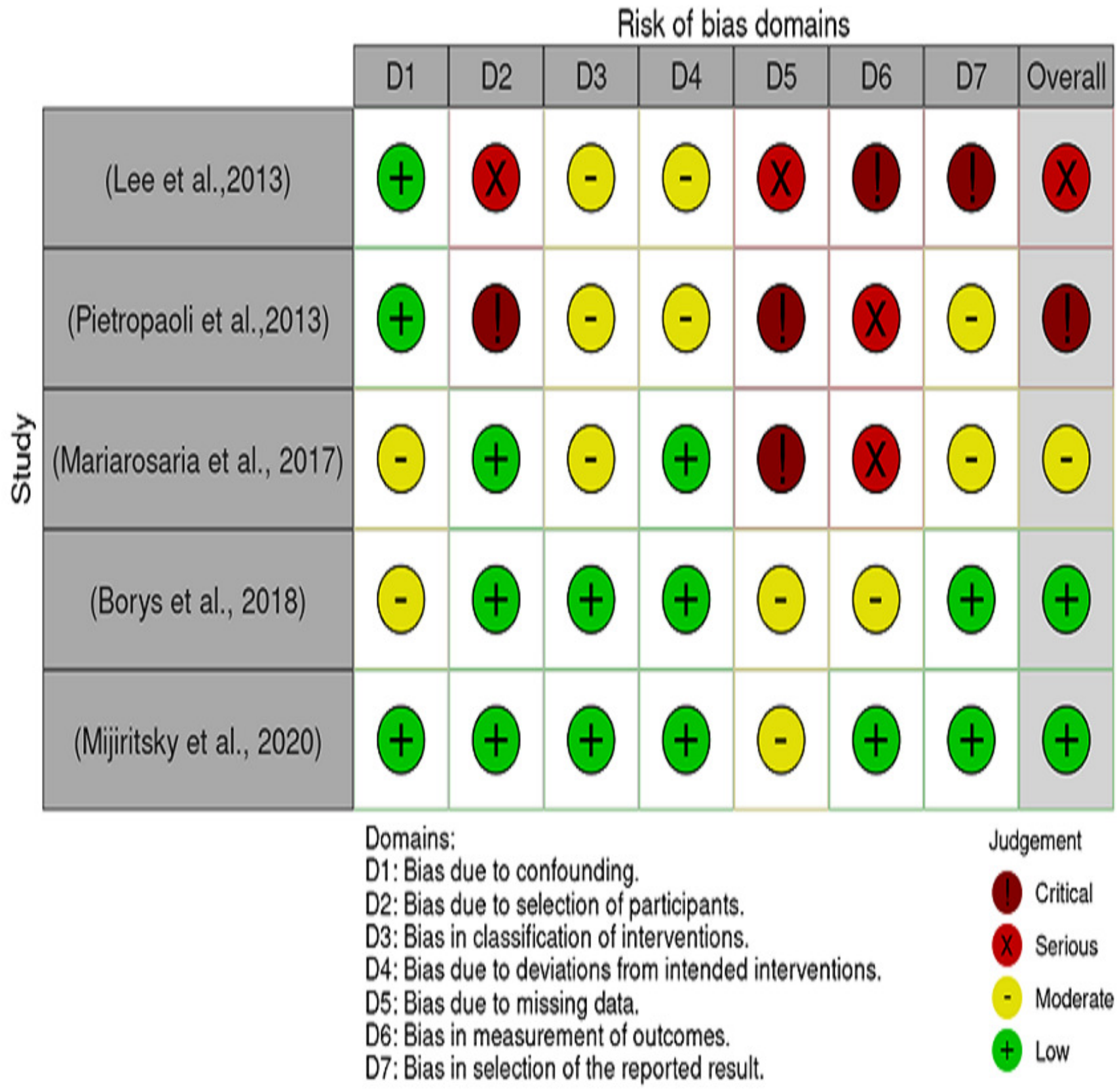


Figure 5

Figure 5.

Risk of Bias assessment of in vitro studies.

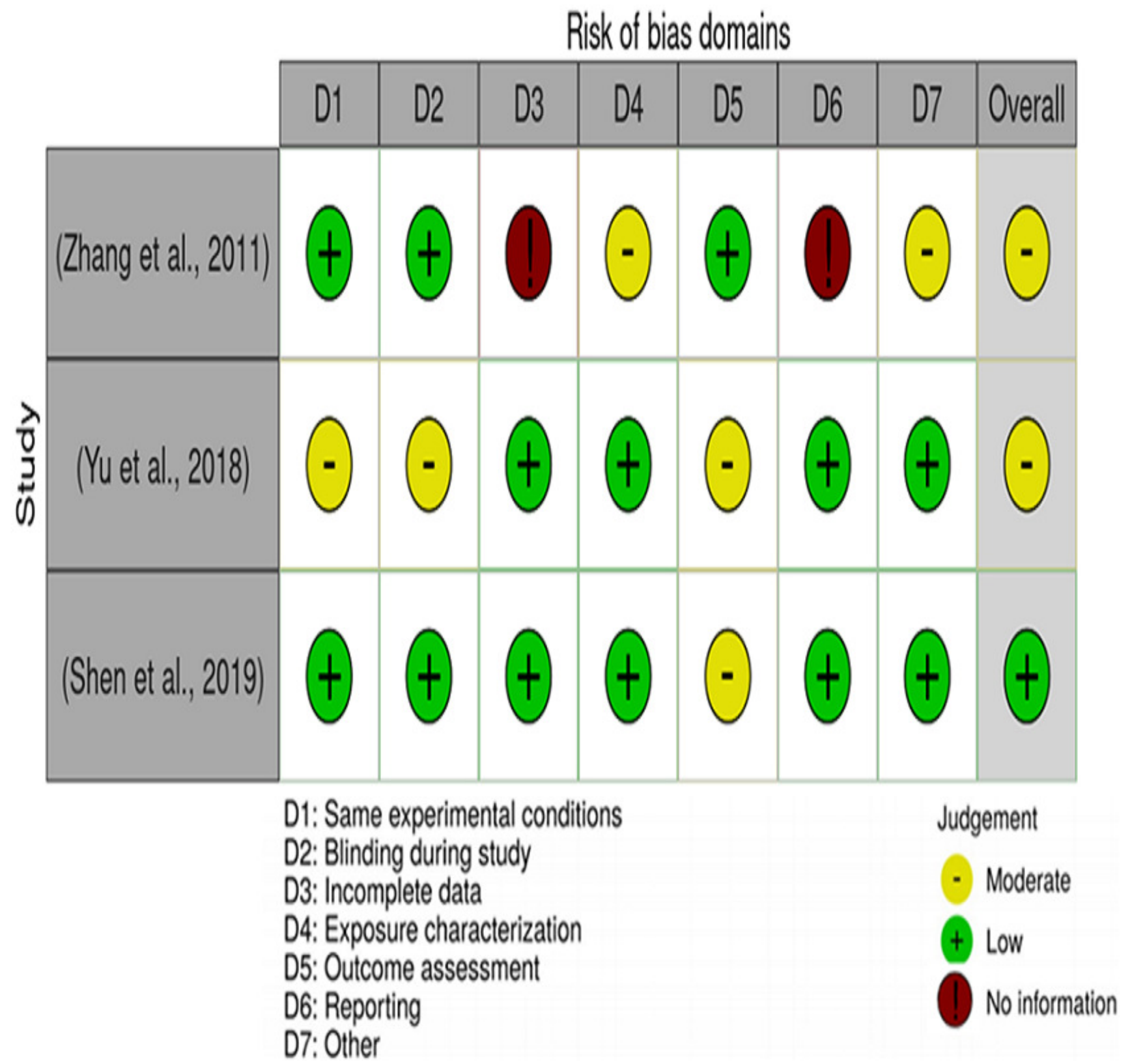




\section{Figure 6}

Figure 6

Schematic figure of the link between dental implant surface, presence of particles release, oxidative stress generation, antioxidant production, and their effects on bone remodeling markers. 


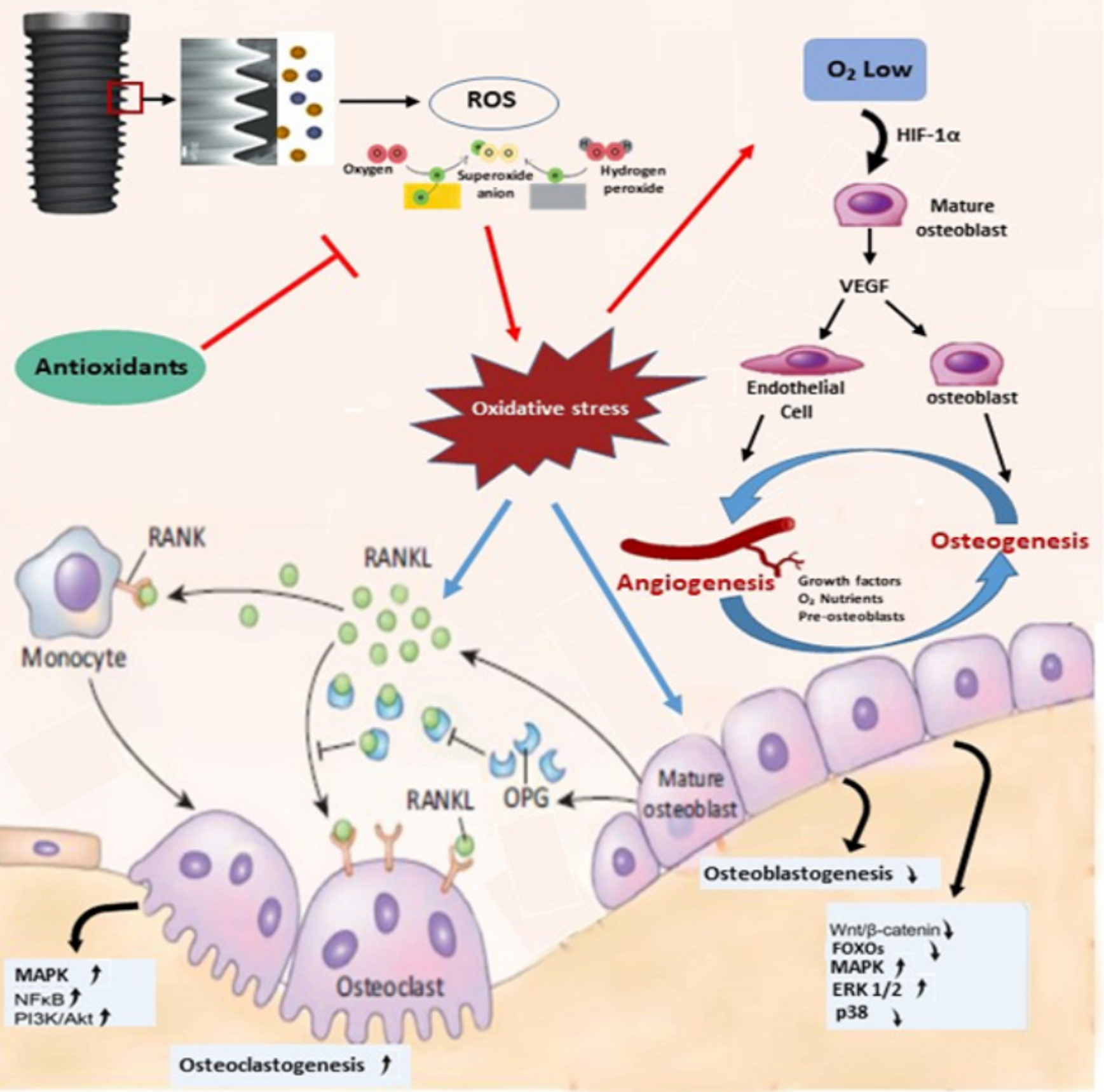




\section{Table 1 (on next page)}

Table 1.

A descriptive summary of the findings are tabulated based on the focused question. 


\begin{tabular}{|c|c|c|c|c|c|c|c|c|c|c|c|c|}
\hline \multirow{2}{*}{ \# } & \multirow{2}{*}{$\begin{array}{c}\text { Autho } \\
\quad r \\
\text { Year }\end{array}$} & \multirow{2}{*}{ Title } & \multirow{2}{*}{$\begin{array}{l}\text { Study } \\
\text { Design }\end{array}$} & \multirow{2}{*}{$\begin{array}{l}\text { In vivo/ In } \\
\text { vitro Studies } \\
\text { Cell type }\end{array}$} & \multicolumn{2}{|c|}{ Biomaterial } & \multirow{2}{*}{ Limitations } & \multirow{2}{*}{ Assay used } & \multirow{2}{*}{$\begin{array}{l}\text { Pathway } \\
\text { Identified }\end{array}$} & \multirow{2}{*}{$\begin{array}{l}\text { Osteogensis/ } \\
\text { Angiogenesis }\end{array}$} & \multirow{2}{*}{$\begin{array}{l}\text { Outcome/ } \\
\text { Findings }\end{array}$} & \multirow{2}{*}{$\begin{array}{c}\text { Quality of } \\
\text { Study } \\
\text { (100) }\end{array}$} \\
\hline & & & & & $\begin{array}{c}\text { Material } \\
\text { used }\end{array}$ & $\begin{array}{c}\text { Biomaterial } \\
\text { Characteristi } \\
\text { cs/ } \\
\text { Dimensions } \\
\end{array}$ & & & & & & \\
\hline 1 & 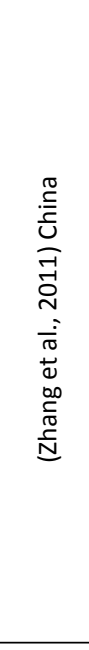 & $\begin{array}{l}\text { Analysis of the } \\
\text { cytotoxicity of } \\
\text { differentially sized } \\
\text { titanium dioxide } \\
\text { nanoparticles in } \\
\text { murine MC3T3-E1 } \\
\text { preosteoblasts }\end{array}$ & 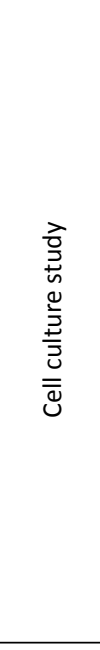 & $\begin{array}{l}\text { MC3T3-E1 } \\
\text { murine } \\
\text { preosteoblast } \\
\mathrm{s}\end{array}$ & $\begin{array}{l}\text { Titanium oxide } \\
\text { nanoparticles } \\
\text { ( } \mathrm{TiO}_{2} \mathrm{NPs} \text { ) }\end{array}$ & $\begin{array}{l}5 \text { and } 32 \mathrm{~nm} \\
\text { in diameter }\end{array}$ & $\begin{array}{l}\text { * The cellular and } \\
\text { molecular cross talk } \\
\text { in bone remodeling } \\
\text { were not identified. } \\
\text { * The effect of } \\
\mathrm{TiO}_{2} \mathrm{NPs} \text { induced } \\
\text { oxidative stress on } \\
\text { the osteogenesis- } \\
\text { angiogenesis } \\
\text { coupling in bone } \\
\text { remodeling were } \\
\text { not identified. }\end{array}$ & $\begin{array}{l}\text { The tetrazolium salt } \\
\text { MTT method and } \\
\text { lactate dehydrogenase } \\
\text { (LDH) assay. } \\
\text { Annexin V apoptosis } \\
\text { detected by a flow } \\
\text { cytometric assay. } \\
\text { TEM analysis. } \\
\text { Mitochondrial } \\
\text { membrane } \\
\text { permeability assay. } \\
\text { RNA extraction and } \\
\text { real-time quantitative } \\
\text { RT-PCR analysis. }\end{array}$ & ND & Osteogenesis & $\begin{array}{l}\mathrm{TiO}_{2} \mathrm{NPs}_{\text {induced a }} \\
\text { time- and dose } \\
\text { dependent } \\
\text { decrease in cell } \\
\text { viability. There was a } \\
\text { significant } \\
\text { increase in lactate } \\
\text { dehydrogenase (LDH) } \\
\text { release, apoptosis } \\
\text { and mitochondrial } \\
\text { membrane } \\
\text { permeability } \\
\text { following short term } \\
\text { exposure of the cells } \\
\text { to } \mathrm{TiO}_{2} \mathrm{NPs} \\
\text { Compared with the } \\
32 \mathrm{~nm} \mathrm{TiO}_{2} \mathrm{NPs}, 5 \\
\mathrm{~nm} \mathrm{TiO}_{2} \mathrm{NPs} \text { were } \\
\text { more toxic. }\end{array}$ & $\begin{array}{c}70 \\
\text { Strong } \\
\text { Evidence }\end{array}$ \\
\hline 2 & 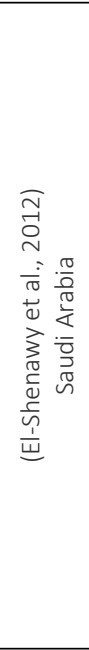 & $\begin{array}{l}\text { Oxidative stress and } \\
\text { antioxidant } \\
\text { responses of liver } \\
\text { and kidney tissue } \\
\text { after implantation } \\
\text { of titanium or } \\
\text { titanium oxide } \\
\text { coated plate in rat } \\
\text { tibiae }\end{array}$ & 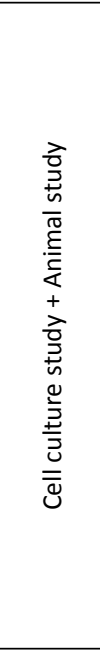 & $\begin{array}{l}\text { Wistar rats } \\
\text { Serum }\end{array}$ & $\begin{array}{l}\mathrm{TiO}_{2} \text { plate } \\
\text { Ti plare }\end{array}$ & $\begin{array}{l}3.0 \times 1.0 \times \\
0.25 \mathrm{~mm}\end{array}$ & $\begin{array}{l}{ }^{*} \text { The cellular and } \\
\text { molecular cross talk } \\
\text { in bone remodeling } \\
\text { were not identified. } \\
{ }^{*} \text { The effect of } \mathrm{TiO}_{2} \\
\text { nanotubes reduced } \\
\text { oxidative stress on } \\
\text { the osteogenesis- } \\
\text { angiogenesis } \\
\text { coupling in bone } \\
\text { remodeling were } \\
\text { not identified. }\end{array}$ & $\begin{array}{l}\text { Plasma mass } \\
\text { spectrometer (ICP- } \\
\text { MS). } \\
\text { Hematology } \\
\text { autoanalyzer } \\
\text { Cell counter (Sysmex, } \\
\text { model KX21N). } \\
\text { Flame photometry. } \\
\text { Bio-Rad protein assay } \\
\text { reagent. } \\
\text { Lipid peroxidation } \\
\text { assay. } \\
\text { Superoxide dismutase } \\
\text { (SOD) activity assay. } \\
\text { Reduced glutathione } \\
\text { assay. } \\
\text { ferric reducing/ } \\
\text { antioxidant power } \\
\text { (FRAP) assay. }\end{array}$ & ND & $\begin{array}{c}\text { NA } \\
\text { oxidative } \\
\text { stress }\end{array}$ & $\begin{array}{l}\text { Ti-implantation could } \\
\text { not decrease } \\
\text { thiobarbituric acid } \\
\text { reactive product } \\
\text { malondialdehyde } \\
\text { (MDA) level. } \mathrm{TiO}_{2} / \mathrm{Ti}- \\
\text { plate did not induce } \\
\text { elevation of } \mathrm{MDA} \text { in } \\
\text { liver and kidney } \\
\text { tissues, however, } \\
\text { some antioxidant } \\
\text { have been changed. } \\
\mathrm{TiO}_{2} / \mathrm{Ti} \text {-plate has less } \\
\text { effect on the redox } \\
\text { stat of rat than Ti- } \\
\text { plate for use as an } \\
\text { artificial surgical } \\
\text { implant. }\end{array}$ & $\begin{array}{c}61.66 \\
\text { Moderate } \\
\text { Evidence }\end{array}$ \\
\hline
\end{tabular}


Bone regeneration around $\mathrm{N}$-acetyl cysteine-loaded nanotube titanium dental implant in rat mandible

\begin{tabular}{|c|c|c|c|c|}
\hline 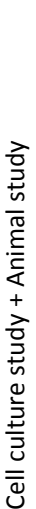 & $\begin{array}{l}\text { MC-3T3 E1 } \\
\text { osteoblast-like } \\
\text { cells. } \\
\text { Sprague } \\
\text { Dawley rats }\end{array}$ & $\begin{array}{l}\text { Ti nanotubes. } \\
\text { Ti nanotube } \\
\text { mini screws. }\end{array}$ & $\begin{array}{l}1 \times 1 \mathrm{~cm} 1 \\
\mathrm{~mm} \text { and } 6 \mathrm{x} \\
6 \mathrm{~cm} 1 \mathrm{~mm} \\
\text { in vitro. } \\
4.5 \mathrm{~mm} \text { in } \\
\text { length and a } \\
\text { diameter of } \\
0.85 \mathrm{~mm} \\
\text { were used } \\
\text { for in vivo. }\end{array}$ & $\begin{array}{l}\text { * The cellular and } \\
\text { molecular cross talk } \\
\text { in bone remodeling } \\
\text { were not identified. } \\
\text { * The effect of Ti } \\
\text { nanotube reduced } \\
\text { oxidative stress on } \\
\text { the osteogenesis- } \\
\text { angiogenesis } \\
\text { coupling in bone } \\
\text { remodeling were } \\
\text { not identified. }\end{array}$ \\
\hline 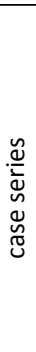 & Human Study & Dental Implant & ND & $\begin{array}{l}\text { * Limitation of the } \\
\text { sample size } \\
\text { * The molecular } \\
\text { pathways that are } \\
\text { involved in } \\
\text { periimplantitis were } \\
\text { not identified. } \\
\text { * Implant } \\
\text { characteristics were } \\
\text { not mentioned. }\end{array}$ \\
\hline 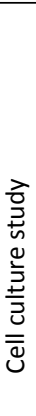 & $\begin{array}{l}\text { Osteoblast } \\
\text { cells }\end{array}$ & $\begin{array}{l}\text { Titanium oxide } \\
\text { nanoparticles } \\
\text { (TiO2-NPs) }\end{array}$ & $\begin{array}{c}\text { less than } 25 \\
\mathrm{~nm} .\end{array}$ & $\begin{array}{l}\text { * The cellular and } \\
\text { molecular cross talk } \\
\text { in bone remodeling } \\
\text { were not identified. } \\
{ }^{*} \text { The effect of } \\
\mathrm{TiO}_{2} \mathrm{NPs} \text { induced } \\
\text { oxidative stress on } \\
\text { the osteogenesis- } \\
\text { angiogenesis } \\
\text { coupling in bone } \\
\text { remodeling were } \\
\text { not identified. }\end{array}$ \\
\hline
\end{tabular}

wettability.

assessment of surface

hydrophobicity and

hydrophilicity.

Cell viability assays.

Total nitric oxide (NO)

analysis.

ELISA.

Western blot analysis.

Micro-computed

tomography $(\mathrm{m}-\mathrm{CT})$

analysis.

(H\&E) staining and

immunohistochemical

(IHC) staining

\begin{tabular}{|c|c|c|c|}
\hline $\begin{array}{c}\text { RANKL } \\
\text { expression }\end{array}$ & Osteogenesis & $\begin{array}{l}\text { MC-3T3-E1 cells } \\
\text { seeded on pure Ti } \\
\text { and nanotube } \\
\text { Ti surfaces increased } \\
\text { the expression of } \\
\text { RANKL and markedly } \\
\text { diminished the } \\
\text { expressions of BMP- } \\
2,-7 \text { and SPARC. } \\
\text { Compared with NLP- } \\
\text { Ti, NLN-Ti surfaces } \\
\text { attenuated the level } \\
\text { of RANKL expression } \\
\text { and expression of } \\
\text { antioxidants } \\
\text { enzymes and bone } \\
\text { formation molecules, } \\
\text { such as BMP-2 and - } \\
7 .\end{array}$ & $\begin{array}{c}86.66 \\
\text { Strong } \\
\text { Evidence }\end{array}$ \\
\hline ND & $\begin{array}{c}\text { NA } \\
\text { oxidative } \\
\text { stress }\end{array}$ & $\begin{array}{l}\text { The chronic } \\
\text { periodontal disease } \\
\text { group showed higher } \\
\text { oxidative stress than } \\
\text { periimplantitis and } \\
\text { healthy groups. } \\
\text { Periimplantitis group } \\
\text { compared to the } \\
\text { healthy one had } \\
\text { higher oxidative } \\
\text { stress levels }\end{array}$ & $\begin{array}{c}65 \\
\text { Moderate } \\
\text { Evidence }\end{array}$ \\
\hline ND & Osteogenesis & $\begin{array}{l}\mathrm{TiO}_{2} \text {-NPs can cause } \\
\text { the decrease of the } \\
\text { survival rate of the } \\
\text { osteoblast and } \\
\text { increase of the } \\
\text { content of } \\
\text { the } \mathrm{LDH} \text { released by } \\
\text { the cell, and with } \\
\text { dosage dependency } \\
\text { effect }\end{array}$ & $\begin{array}{c}71.66 \\
\text { Strong } \\
\text { Evidence }\end{array}$ \\
\hline
\end{tabular}
cytoactive detection. $\mathrm{LDH}$ reagent kit for cytotoxicity detection ROS detection reagent kit.

RIPA cell lysis.

Transmission electron microscopy (TEM)

Zetasizer particle size

analyzer

Malvern Instrument,

Ultrasonic oscillation

instrument.

contrast microscope. diminished the

molecules,

ence 
Titanium dioxide nanoparticles

enhance production

of superoxide anion

and alter the

antioxidant system

in human

osteoblast cells

Oxidative Stress

Evaluation During

Perimplantar Bone

Resorption in

Immediate Post-

Extractive Implant

\begin{tabular}{|c|c|c|c|c|c|c|c|c|c|}
\hline 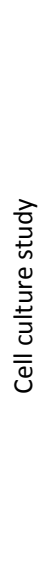 & $\begin{array}{l}\text { hFOB } 1.19 \\
\text { human } \\
\text { osteoblast } \\
\text { cells }\end{array}$ & $\mathrm{TiO}_{2} \mathrm{NPs}$ & $\begin{array}{c}\mathrm{TiO}_{2} \mathrm{NPs} \\
\text { size 5-15 nm }\end{array}$ & $\begin{array}{l}\text { * The cellular and } \\
\text { molecular cross talk } \\
\text { in bone remodeling } \\
\text { were not identified. } \\
\text { * The effect of } \\
\mathrm{TiO}_{2} \mathrm{NPs} \text { induced } \\
\text { oxidative stress on } \\
\text { the osteogenesis- } \\
\text { angiogenesis } \\
\text { coupling in bone } \\
\text { remodeling were } \\
\text { not identified. }\end{array}$ & $\begin{array}{l}\text { Water-soluble } \\
\text { tetrazolium salt (WST) } \\
1 \text { assay. } \\
\text { Mitochondrial activity } \\
\text { assay. } \\
\text { Transmission electron } \\
\text { microscope (TEM) } \\
\text { analysis. } \\
\text { Lactate } \\
\text { dehydrogenase (LDH) } \\
\text { assay. } \\
\text { Alkaline phosphatase } \\
\text { (ALP) activity. } \\
\text { Flow cytometry. } \\
\text { Total antioxidant } \\
\text { capacity. }\end{array}$ & $\begin{array}{l}\text { SIR3 ROS } \\
\text { pathway }\end{array}$ & Osteogenesis & $\begin{array}{l}\text { Significant positive } \\
\text { correlation between } \\
\text { SIR3 and MnSOD at } \\
\text { the protein level and } \\
\text { a significant negative } \\
\text { correlation between } \\
\text { decreased SIR3 } \\
\text { protein level and } \\
\text { increased O2•- level }\end{array}$ & $\begin{array}{c}83.33 \\
\text { Strong } \\
\text { Evidence }\end{array}$ \\
\hline$\stackrel{5}{\longleftarrow}$ & Human study & Dental Implant & $\begin{array}{l}\text { V3 } \mathrm{MIS}^{\circledR} \\
\text { implant }\end{array}$ & $\begin{array}{l}\text { * The molecular } \\
\text { pathways that are } \\
\text { involved in } \\
\text { perimplantar bone } \\
\text { resorption were not } \\
\text { identified. } \\
\text { * The cellular and } \\
\text { molecular cross talk } \\
\text { in bone remodeling } \\
\text { were not identified. } \\
\text { * The effect of } \\
\text { biomaterial induced } \\
\text { oxidative stress on } \\
\text { the osteogenesis- } \\
\text { angiogenesis } \\
\text { coupling in bone } \\
\text { remodeling were } \\
\text { not identified. }\end{array}$ & $\begin{array}{l}\text { Thiobarbituric acid } \\
\text { reactive substances } \\
\text { (TBARs). } \\
\text { Nitrite assay. } \\
\text { Immunoenzymatic } \\
\text { assay for interleukin. } \\
\text { Cicloxygenase-2 (COX- } \\
\text { 2) } \\
\text { immunoprecipitation. }\end{array}$ & ND & $\begin{array}{c}\text { Osteoclastoge } \\
\text { nesis }\end{array}$ & $\begin{array}{l}\text { An increase, during } \\
\text { implant integration } \\
\text { between the first and } \\
\text { third week, of both } \\
\text { oxidative stress } \\
\text { markers and } \\
\text { cyclooxygenase-2 } \\
\text { expression. At } \\
\text { sixteen week the } \\
\text { parameters } \\
\text { evaluated returned } \\
\text { to basal values. }\end{array}$ & $\begin{array}{c}63.33 \\
\text { Moderate } \\
\text { Evidence }\end{array}$ \\
\hline
\end{tabular}



Titanium Alloy Leads to Redox Abnormalities,

Oxidative Stress, and Oxidative

Damage in Patients

Treated for

Mandible Fractures

\begin{tabular}{|c|c|c|c|c|c|c|c|c|c|}
\hline$\underset{\mathscr{X}}{\longleftarrow}$ & Human study & $\begin{array}{l}\text { Ti4AI4V } \\
\text { Titanium alloy }\end{array}$ & $\begin{array}{l}\text { Gray- } \\
\text { pigmented } \\
\text { periosteum } \\
\text { adhered to } \\
\text { the titanium } \\
\text { miniplates }\end{array}$ & $\begin{array}{l}\text { Only the most } \\
\text { commonly used } \\
\text { biomarkers of } \\
\text { oxidative stress; } \\
\text { therefore were } \\
\text { evaluated, the } \\
\text { assessment of } \\
\text { other parameters } \\
\text { may lead to } \\
\text { different } \\
\text { observations and } \\
\text { conclusions. }\end{array}$ & $\begin{array}{l}\text { Antioxidant Assays } \\
\text { Total antioxidant } \\
\text { capacity (TAC). } \\
\text { Oxidative Damage } \\
\text { Determination Assay }\end{array}$ & ND & $\begin{array}{c}\text { Osteoclastoge } \\
\text { nesis }\end{array}$ & $\begin{array}{l}\text { Increased } \\
\text { activity/concentratio } \\
\mathrm{n} \text { of antioxidants } \\
\text { both in the } \\
\text { mandibular } \\
\text { periosteum and } \\
\text { plasma/erythrocytes } \\
\text { of patients with } \\
\text { titanium mandibular } \\
\text { fixations. }\end{array}$ & $\begin{array}{c}77.66 \\
\text { Strong } \\
\text { Evidence }\end{array}$ \\
\hline 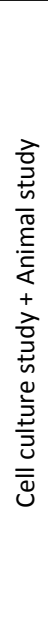 & HUVEC & $\begin{array}{l}\text { Ti4Al4V } \\
\text { Titanium alloy }\end{array}$ & $\begin{array}{l}\text { 1) Circular } \\
\text { disks } \\
\text { 2)Sscrews. } \\
\text { Circular disks } \\
\text { were used in } \\
\text { experiments } \\
\text { in vitro and } \\
\text { screws in } \\
\text { study in vivo. }\end{array}$ & $\begin{array}{l}\text { * The cellular and } \\
\text { molecular cross talk } \\
\text { in bone remodeling } \\
\text { were not identified. } \\
\text { * The effect of } \\
\text { biomaterial induced } \\
\text { oxidative stress on } \\
\text { the osteogenesis- } \\
\text { angiogenesis } \\
\text { coupling in bone } \\
\text { remodeling were } \\
\text { not identified. }\end{array}$ & $\begin{array}{l}\text { Immunofluorescent } \\
\text { histochemistry. } \\
\text { Real-time quantitative } \\
\text { PCR (qPCR). } \\
\text { Micro-CT analysis. } \\
\text { MTT Assay. } \\
\text { Matrigel tube- } \\
\text { formation assay. } \\
\text { Wound-healing assay. } \\
\text { ROS assay. } \\
\text { Western blot analysis. } \\
\text { Immunohistochemical } \\
\text { evaluation. } \\
\text { ATP assay. } \\
\text { Analysis of } \\
\text { mitochondrial } \\
\text { membrane potential } \\
\text { (MMP). }\end{array}$ & $\begin{array}{c}\text { NOX, APO, } \\
\text { Nog and } \\
\text { Bmp-2 }\end{array}$ & $\begin{array}{l}\text { osteogenesis, } \\
\text { angiogensis } \\
\text { and } \\
\text { adipogenesis }\end{array}$ & $\begin{array}{l}\text { The advanced } \\
\text { glycation end } \\
\text { products (AGEs)- } \\
\text { related and NOX- } \\
\text { triggered cellular } \\
\text { oxidative stress leads } \\
\text { to vascular } \\
\text { endothelial cell (VEC) } \\
\text { dysfunction and } \\
\text { angiogenesis } \\
\text { impairment at the } \\
\text { bone-implant } \\
\text { interface (BII), which } \\
\text { plays a critical role in } \\
\text { the compromised } \\
\text { implant } \\
\text { osteointegration } \\
\text { under diabetic } \\
\text { conditions. }\end{array}$ & $\begin{array}{c}90 \\
\text { Strong } \\
\text { Evidence }\end{array}$ \\
\hline
\end{tabular}




\begin{tabular}{|c|c|c|c|c|c|c|c|c|c|c|c|c|}
\hline 10 & 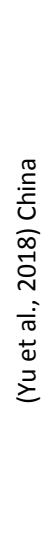 & $\begin{array}{l}\text { Osteogenesis } \\
\text { potential of } \\
\text { different titania } \\
\text { nanotubes in } \\
\text { oxidative stress } \\
\text { microenvironment }\end{array}$ & 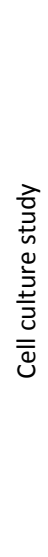 & $\begin{array}{l}\text { Calvaria } \\
\text { osteoblasts }\end{array}$ & Titanium foils & $\begin{array}{l}\text { TNT30, } \\
\text { TNT70 } \\
\text { and TNT110 }\end{array}$ & $\begin{array}{l}\text { * The cellular and } \\
\text { molecular cross talk } \\
\text { in bone remodeling } \\
\text { were not identified. } \\
{ }^{*} \text { The effect of } \mathrm{TiO}_{2} \\
\text { nantube reduced } \\
\text { oxidative stress on } \\
\text { the osteogenesis- } \\
\text { angiogenesis } \\
\text { coupling in bone } \\
\text { remodeling were } \\
\text { not identified. }\end{array}$ & $\begin{array}{l}\text { Scanning electron } \\
\text { microscopy. } \\
\text { Atomic force } \\
\text { microscopy. } \\
\text { X-ray diffraction. } \\
\text { Video-based optical } \\
\text { system. } \\
\text { MTT. } \\
\text { BCA assay kit. } \\
\text { confocal laser } \\
\text { scanning microscopy. } \\
\text { quantitative- } \\
\text { polymerase chain } \\
\text { reaction (q-PCR). }\end{array}$ & Wnt signals & Osteogenesis & $\begin{array}{l}\text { Large nanotubes } \\
\text { displayed strong } \\
\text { capacities to improve } \\
\text { cell adhesion, } \\
\text { survival and } \\
\text { differentiation of } \\
\text { osteoblasts after } \\
\mathrm{H}_{2} \mathrm{O}_{2} \text { treatment. }\end{array}$ & $\begin{array}{c}86.66 \\
\text { Strong } \\
\text { Evidence }\end{array}$ \\
\hline 11 & 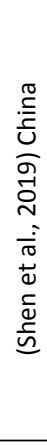 & $\begin{array}{l}\text { Titania nanotubes } \\
\text { promote } \\
\text { osteogenesis via } \\
\text { mediating crosstalk } \\
\text { between } \\
\text { macrophages and } \\
\text { MSCs under } \\
\text { oxidative stress }\end{array}$ & 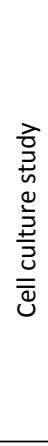 & $\begin{array}{l}\text { Mesenchymal } \\
\text { stem cells } \\
\text { (MSCs). } \\
\text { RAW264.7 } \\
\text { cells. }\end{array}$ & $\begin{array}{l}\text { Titanium foils. } \\
\text { Titanium } \\
\text { nantubes }\end{array}$ & $\begin{array}{l}\text { TNT30, } \\
\text { TNT70 and } \\
\text { TNT110 }\end{array}$ & $\begin{array}{l}\text { Should be } \\
\text { implemented in } \\
\text { vivo and humans. }\end{array}$ & \begin{tabular}{|l|} 
Confocal laser \\
scanning microscope. \\
Cell viability assay. \\
Nitrous oxide (NO) \\
assay \\
ELISA. \\
real-time \\
quantitative- \\
polymerase chain \\
reaction (q-PCR) \\
technique. \\
Western Blot (WB) \\
technique \\
\end{tabular} & $\begin{array}{c}\text { integrin/FA } \\
\text { K-mediated } \\
\text { MAPK and } \\
\text { NFKB } \\
\text { signals }\end{array}$ & Osteogenesis & $\begin{array}{l}\text { large nanotubes (110 } \\
\text { nm) could recruit } \\
\text { more MSCs to the } \\
\text { injury site than Ti } \\
\text { and TNT30 } \\
\text { substrates by } \\
\text { increasing the } \\
\text { chemokine } \\
\text { expressions of } \\
\text { RAW264.7 cells } \\
\text { under OS. }\end{array}$ & $\begin{array}{c}99.33 \\
\text { Strong } \\
\text { Evidence }\end{array}$ \\
\hline 12 & 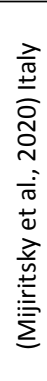 & $\begin{array}{l}\text { Presence of ROS in } \\
\text { Inflammatory } \\
\text { Environment of } \\
\text { Peri-Implantitis } \\
\text { Tissue: In Vitro and } \\
\text { In Vivo Human } \\
\text { Evidence }\end{array}$ & 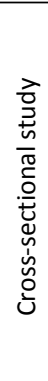 & Human study & Dental Implant & ND & $\begin{array}{l}\text { * Limitation of the } \\
\text { sample size } \\
{ }^{*} \text { The molecular } \\
\text { pathways that are } \\
\text { involved in } \\
\text { periimplantitis were } \\
\text { not identified. } \\
\text { * Implant } \\
\text { characterestics } \\
\text { were not } \\
\text { mentioned. }\end{array}$ & $\begin{array}{l}\text { Immunohistochemistr } \\
\text { y and } \\
\text { Histomorpholgical } \\
\text { Analyses. } \\
\text { Immunofluorescence } \\
\text { Staining. } \\
\text { Transmission Electron } \\
\text { Microscopy (TEM). } \\
\text { RNeasy Mini Kit. }\end{array}$ & $\begin{array}{c}\text { WNT, } \\
\text { HEDGEHOG } \\
\text {, and FOXO }\end{array}$ & $\begin{array}{l}\text { Osteogenesis } \\
\text { and } \\
\text { adipogenesis }\end{array}$ & $\begin{array}{l}\text { osteogenesis down } \\
\text { expressed in peri- } \\
\text { implantitis and up } \\
\text { regulated in the } \\
\text { control. }\end{array}$ & $\begin{array}{c}78.33 \\
\text { Strong } \\
\text { Evidence }\end{array}$ \\
\hline
\end{tabular}


$\mathrm{TiO}_{2}$ Nanotubes

Alleviate Diabetes-

Induced

Osteogenetic

Inhibition
Bioadaptation of implants to In vitro and In vivo oxidative stress pathological conditions via nanotopographyinduced FoxO1 signaling pathways to enhance Osteoimmunal regeneration

\begin{tabular}{|c|c|c|c|c|c|c|c|c|c|}
\hline 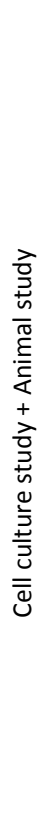 & $\begin{array}{l}\text { pre- } \\
\text { osteoblastic } \\
\text { cell line, } \\
\text { MC3T3-E1 } \\
\text { Sprague- } \\
\text { Dawley (SD) } \\
\text { rats. }\end{array}$ & $\begin{array}{l}\text { In vitro; Ti discs } \\
\text { divided into } 3 \\
\text { groups - } \\
\text { mechanically } \\
\text { polished (MP } \\
\text { group), } \\
\text { sandblasted } \\
\text { and acidetched } \\
\text { (SLA group), } \\
\text { and oxidized } \\
\mathrm{TiO}_{2} \text { nanotubes } \\
\text { (TNT group). } \\
\text { In vivo; pure Ti } \\
\text { implants }\end{array}$ & $\begin{array}{l}\text { In vitro; } \\
\text { dimensions: } \\
10.0 \times 10.0 \times \\
0.3 \mathrm{~mm}^{4} \text { or } \\
20.0 \times 20.0 \times \\
0.3 \mathrm{~mm}^{4} \text {. } \\
\text { In vivo; a } \\
\text { diameter } \\
\text { and length of } \\
2 \text { and } 4 \mathrm{~mm} \text {. }\end{array}$ & $\begin{array}{l}\text { * The cellular and } \\
\text { molecular cross talk } \\
\text { in bone remodeling } \\
\text { were not identified. } \\
\text { * The effect of } \mathrm{TiO}_{2} \\
\text { nantube reduced } \\
\text { oxidative stress on } \\
\text { the osteogenesis- } \\
\text { angiogenesis } \\
\text { coupling in bone } \\
\text { remodeling were } \\
\text { not identified. }\end{array}$ & $\begin{array}{l}\text { CCK-8 assay. } \\
\text { Alkaline phosphatase } \\
\text { (ALP) assay. } \\
\text { osteopontin (OPN) } \\
\text { assay. } \\
\text { Western blot test. } \\
\text { Alizarin Red staining. } \\
\text { Flow cytometry. } \\
\text { Superoxide Dismutase } \\
\text { (SOD) activity sssay. } \\
\text { micro-CT scan. }\end{array}$ & ND & Osteogenesis & $\begin{array}{l}\text { High-glucose } \\
\text { conditions inhibited } \\
\text { ALP and OPN } \\
\text { expressions on } \\
\text { different modified Ti } \\
\text { surfaces, TNT surface } \\
\text { could alleviate the } \\
\text { inhibition of ALP and } \\
\text { OPN expressions } \\
\text { under high-glucose } \\
\text { conditions. } \\
\text { High-glucose } \\
\text { conditions inhibited } \\
\text { osteogenesis on } \\
\text { different modified Ti } \\
\text { surfaces, The TNT } \\
\text { surface could } \\
\text { alleviate the } \\
\text { inhibition of } \\
\text { mineralization when } \\
\text { compared with the } \\
\text { SLA surface under } \\
\text { high glucose } \\
\text { conditions. }\end{array}$ & $\begin{array}{c}88.33 \\
\text { Strong } \\
\text { Evidence }\end{array}$ \\
\hline 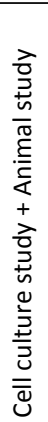 & $\begin{array}{l}\text { 1) BMSCs } \\
\text { 2) RAW264.7 }\end{array}$ & $\begin{array}{l}\mathrm{TiO}_{2} \text { nanotube } \\
\text { (TNT). }\end{array}$ & $\begin{array}{l}\text { 1) Pure Ti } \\
\text { foils } \\
\text { 2) Cylinder- } \\
\text { shaped } \\
\text { (disck)pure } \\
\text { Ti implants. }\end{array}$ & $\begin{array}{l}\text { * The cellular and } \\
\text { molecular cross talk } \\
\text { in bone remodeling } \\
\text { were not identified. } \\
\text { * The effect of } \\
\text { biomaterial induced } \\
\text { oxidative stress on } \\
\text { the osteogenesis- } \\
\text { angiogenesis } \\
\text { coupling in bone } \\
\text { remodeling were } \\
\text { not identified. }\end{array}$ & $\begin{array}{l}\text { Scanning electron } \\
\text { microscopy. } \\
\text { Laser scanning } \\
\text { confocal microscope } \\
\text { profilometer. } \\
\text { Contact angle } \\
\text { analyzer. }\end{array}$ & $\begin{array}{c}\text { FoxO1- } \\
\text { induced } \\
\text { oxidation } \\
\text { resistance } \\
\text { and anti- } \\
\text { inflammato } \\
\text { ry } \\
\text { osteoimmu } \\
\text { nity. }\end{array}$ & Osteogenesis & $\begin{array}{l}\text { Nanoscale TNT } \\
\text { coatings on titanium } \\
\text { implants exhibited } \\
\text { superior } \\
\text { osteogenesis and } \\
\text { osseointegration } \\
\text { compared with } \\
\text { microscale SLA } \\
\text { surfaces. }\end{array}$ & $\begin{array}{c}86.66 \\
\text { Strong } \\
\text { Evidence }\end{array}$ \\
\hline
\end{tabular}




\section{Table 2 (on next page)}

Table 2.

Critical Appraisal Skills Program Checklist for Quality Assessment of Observational Studies (CASP) (Long et al., 2020). 


\begin{tabular}{|c|c|c|c|c|c|c|c|c|c|c|c|c|c|c|c|c|c|c|c|c|c|c|c|c|c|c|c|c|c|c|c|c|}
\hline \multirow{2}{*}{$\begin{array}{c}\text { No. } \\
1\end{array}$} & \multirow{2}{*}{$\begin{array}{l}\text { Study Authors } \\
\begin{array}{l}\text { Zhang et al., } 2011 \\
\text { (China) }\end{array}\end{array}$} & \multicolumn{3}{|c|}{$\begin{array}{l}\text { Critical Appraisal } \\
\text { of Introduction } \\
16.65 \%\end{array}$} & \multicolumn{10}{|c|}{$\begin{array}{l}\text { Critical Appraisal of Methodology } \\
26.64 \%\end{array}$} & \multicolumn{17}{|c|}{$\begin{array}{l}\text { Critical Appraisal of Results and Discussion } \\
56.61 \%\end{array}$} & \multirow{2}{*}{$\begin{array}{c}\text { CASP Score } \\
100 \% \\
70 \\
\text { Strong } \\
\text { Evidence } \\
\end{array}$} \\
\hline & & $\checkmark$ & $\checkmark$ & $\checkmark$ & $\checkmark$ & $x$ & $\checkmark$ & $x$ & $\checkmark$ & $\checkmark$ & $x$ & $\checkmark$ & $\checkmark$ & $x$ & $\checkmark$ & $x$ & $\checkmark$ & $\checkmark$ & $x$ & $\checkmark$ & $x$ & $\checkmark$ & $x$ & $x$ & $\checkmark$ & $x$ & $\checkmark$ & $\checkmark$ & $\checkmark$ & $\checkmark$ & $\checkmark$ & \\
\hline 2 & $\begin{array}{l}\text { El-Shenawy et al., } \\
2012 \text { (Saudi Arabia) }\end{array}$ & $\checkmark$ & $\checkmark$ & $\checkmark$ & $\checkmark$ & $x$ & $\checkmark$ & $x$ & $\checkmark$ & $\checkmark$ & $x$ & $\checkmark$ & $\checkmark$ & $x$ & $\checkmark$ & $x$ & $\checkmark$ & $\checkmark$ & $x$ & $\checkmark$ & $\checkmark$ & $x$ & $\checkmark$ & $x$ & $\checkmark$ & $x$ & $\checkmark$ & $x$ & $\checkmark$ & $\checkmark$ & $\checkmark$ & $\begin{array}{c}61.66 \\
\text { Moderate } \\
\text { Evidence }\end{array}$ \\
\hline 3 & $\begin{array}{l}\text { Lee et al.,2013 } \\
\text { (Korea) }\end{array}$ & $\checkmark$ & $\checkmark$ & $\checkmark$ & $\checkmark$ & $\checkmark$ & $\checkmark$ & $\checkmark$ & $\checkmark$ & $\checkmark$ & $\checkmark$ & $\checkmark$ & $\checkmark$ & $\checkmark$ & $\checkmark$ & $\checkmark$ & $\checkmark$ & $\checkmark$ & $\checkmark$ & $\checkmark$ & $x$ & $\checkmark$ & $\checkmark$ & $\checkmark$ & $\checkmark$ & $x$ & $x$ & $\checkmark$ & $\checkmark$ & $\checkmark$ & $\checkmark$ & $\begin{array}{c}86.66 \\
\text { Strong } \\
\text { Evidence }\end{array}$ \\
\hline 4 & $\begin{array}{l}\text { Pietropaoli et } \\
\text { al.,2013 (Italy) }\end{array}$ & $\checkmark$ & $\checkmark$ & $\checkmark$ & $\checkmark$ & $x$ & $\checkmark$ & $x$ & $\checkmark$ & $\checkmark$ & $x$ & $\checkmark$ & $\checkmark$ & $x$ & $\checkmark$ & $x$ & $\checkmark$ & $\checkmark$ & $x$ & $\checkmark$ & $x$ & $\checkmark$ & $x$ & $x$ & $\checkmark$ & $x$ & $\checkmark$ & $x$ & $\checkmark$ & $\checkmark$ & $\checkmark$ & $\begin{array}{c}65 \\
\text { Moderate } \\
\text { Evidence }\end{array}$ \\
\hline 5 & $\begin{array}{l}\text { Xie et al., } 2014 \\
\text { (China) }\end{array}$ & $\checkmark$ & $\checkmark$ & $\checkmark$ & $\checkmark$ & $x$ & $\checkmark$ & $x$ & $\checkmark$ & $\checkmark$ & $x$ & $\checkmark$ & $\checkmark$ & $x$ & $\checkmark$ & $\checkmark$ & $\checkmark$ & $\checkmark$ & $x$ & $\checkmark$ & $x$ & $\checkmark$ & $x$ & $x$ & $\checkmark$ & $x$ & $\checkmark$ & $\checkmark$ & $\checkmark$ & $\checkmark$ & $\checkmark$ & $\begin{array}{c}71.66 \\
\text { Strong } \\
\text { Evidence }\end{array}$ \\
\hline 6 & $\begin{array}{l}\text { Niska et al.,2015 } \\
\text { (Poland) }\end{array}$ & $\checkmark$ & $\checkmark$ & $\checkmark$ & $\checkmark$ & $\checkmark$ & $\checkmark$ & $x$ & $\checkmark$ & $\checkmark$ & $\checkmark$ & $\checkmark$ & $\checkmark$ & $\checkmark$ & $\checkmark$ & $\checkmark$ & $\checkmark$ & $\checkmark$ & $x$ & $\checkmark$ & $x$ & $\checkmark$ & $\checkmark$ & $x$ & $\checkmark$ & $x$ & $\checkmark$ & $\checkmark$ & $\checkmark$ & $\checkmark$ & $\checkmark$ & $\begin{array}{c}83.33 \\
\text { Strong } \\
\text { Evidence }\end{array}$ \\
\hline 7 & $\begin{array}{l}\text { Mariarosaria et al., } \\
2017 \text { (Italy) }\end{array}$ & $\checkmark$ & $\checkmark$ & $\checkmark$ & $\checkmark$ & $x$ & $\checkmark$ & $x$ & $\checkmark$ & $\checkmark$ & $x$ & $\checkmark$ & $\checkmark$ & $x$ & $\checkmark$ & $x$ & $\checkmark$ & $\checkmark$ & $x$ & $\checkmark$ & $\checkmark$ & $x$ & $\checkmark$ & $x$ & $\checkmark$ & $x$ & $\checkmark$ & $x$ & $\checkmark$ & $\checkmark$ & $\checkmark$ & $\begin{array}{c}63.33 \\
\text { Moderate } \\
\text { Evidence }\end{array}$ \\
\hline 8 & $\begin{array}{l}\text { Borys et al., } 2018 \\
\text { (Poland) }\end{array}$ & $\checkmark$ & $\checkmark$ & $\checkmark$ & $\checkmark$ & $\checkmark$ & $\checkmark$ & $x$ & $\checkmark$ & $\checkmark$ & $\checkmark$ & $\checkmark$ & $\checkmark$ & $x$ & $\checkmark$ & $\checkmark$ & $\checkmark$ & $\checkmark$ & $x$ & $\checkmark$ & $x$ & $\checkmark$ & $\checkmark$ & $\checkmark$ & $\checkmark$ & $\checkmark$ & $x$ & $x$ & $\checkmark$ & $\checkmark$ & $\checkmark$ & $\begin{array}{c}77.66 \\
\text { Strong } \\
\text { Evidence }\end{array}$ \\
\hline 9 & $\begin{array}{l}\text { Hu et al., } 2018 \\
\text { (China) }\end{array}$ & $\checkmark$ & $\checkmark$ & $\checkmark$ & $\checkmark$ & $\checkmark$ & $\checkmark$ & $\checkmark$ & $\checkmark$ & $\checkmark$ & $\checkmark$ & $\checkmark$ & $\checkmark$ & $\checkmark$ & $\checkmark$ & $\checkmark$ & $\checkmark$ & $\checkmark$ & $\checkmark$ & $\checkmark$ & $x$ & $\checkmark$ & $\checkmark$ & $\checkmark$ & $\checkmark$ & $\checkmark$ & $x$ & $\checkmark$ & $\checkmark$ & $\checkmark$ & $\checkmark$ & $\begin{array}{c}90 \\
\text { Strong } \\
\text { Evidence }\end{array}$ \\
\hline 10 & $\begin{array}{l}\text { Yu et al., } 2018 \\
\text { (China) }\end{array}$ & $\checkmark$ & $\checkmark$ & $\checkmark$ & $\checkmark$ & $\checkmark$ & $\checkmark$ & $\checkmark$ & $\checkmark$ & $\checkmark$ & $\checkmark$ & $\checkmark$ & $\checkmark$ & $\checkmark$ & $\checkmark$ & $\checkmark$ & $\checkmark$ & $\checkmark$ & $\checkmark$ & $\checkmark$ & $x$ & $\checkmark$ & $\checkmark$ & $\checkmark$ & $\checkmark$ & $x$ & $x$ & $\checkmark$ & $\checkmark$ & $\checkmark$ & $\checkmark$ & $\begin{array}{c}86.66 \\
\text { Strong } \\
\text { Evidence }\end{array}$ \\
\hline 11 & $\begin{array}{l}\text { Shen et al., } 2019 \\
\text { (China) }\end{array}$ & $\checkmark$ & $\checkmark$ & $\checkmark$ & $\checkmark$ & $\checkmark$ & $\checkmark$ & $\checkmark$ & $\checkmark$ & $\checkmark$ & $\checkmark$ & $\checkmark$ & $\checkmark$ & $\checkmark$ & $\checkmark$ & $\checkmark$ & $\checkmark$ & $\checkmark$ & $\checkmark$ & $\checkmark$ & $\checkmark$ & $\checkmark$ & $\checkmark$ & $\checkmark$ & $\checkmark$ & $\checkmark$ & $\checkmark$ & $\checkmark$ & $\checkmark$ & $\checkmark$ & $\checkmark$ & $\begin{array}{c}98.33 \\
\text { Strong } \\
\text { Evidence }\end{array}$ \\
\hline 12 & $\begin{array}{l}\text { Mijiritsky et al., } \\
2020 \text { (Italy) }\end{array}$ & $\checkmark$ & $\checkmark$ & $\checkmark$ & $\checkmark$ & $\checkmark$ & $\checkmark$ & $x$ & $\checkmark$ & $\checkmark$ & $\checkmark$ & $\checkmark$ & $\checkmark$ & $x$ & $\checkmark$ & $\checkmark$ & $\checkmark$ & $\checkmark$ & $x$ & $\checkmark$ & $x$ & $\checkmark$ & $\checkmark$ & $\checkmark$ & $\checkmark$ & $\checkmark$ & $\checkmark$ & $x$ & $\checkmark$ & $\checkmark$ & $\checkmark$ & $\begin{array}{c}78.33 \\
\text { Strong } \\
\text { Evidence }\end{array}$ \\
\hline 13 & $\begin{array}{l}\text { Yang et al., } 2020 \\
\text { (China) }\end{array}$ & $\checkmark$ & $\checkmark$ & $\checkmark$ & $\checkmark$ & $\checkmark$ & $\checkmark$ & $\checkmark$ & $\checkmark$ & $\checkmark$ & $\checkmark$ & $\checkmark$ & $\checkmark$ & $\checkmark$ & $\checkmark$ & $\checkmark$ & $\checkmark$ & $\checkmark$ & $\checkmark$ & $\checkmark$ & $x$ & $\checkmark$ & $\checkmark$ & $\checkmark$ & $\checkmark$ & $\checkmark$ & $x$ & $\checkmark$ & $\checkmark$ & $\checkmark$ & $\checkmark$ & $\begin{array}{c}88.33 \\
\text { Strong } \\
\text { Evidence }\end{array}$ \\
\hline
\end{tabular}




\begin{tabular}{|c|c|c|c|c|c|c|c|c|c|c|c|c|c|c|c|c|c|c|c|c|c|c|c|c|c|c|c|c|c|c|c|c|}
\hline 14 & $\begin{array}{l}\text { Huang et al., } 2021 \\
\text { (China) }\end{array}$ & $\checkmark$ & $\checkmark$ & $\checkmark$ & $\checkmark$ & $\checkmark$ & $\checkmark$ & $\checkmark$ & $\checkmark$ & $\checkmark$ & $\checkmark$ & $\checkmark$ & $\checkmark$ & $\checkmark$ & $\checkmark$ & $\checkmark$ & $\checkmark$ & $\checkmark$ & $\checkmark$ & $\checkmark$ & $x$ & $\checkmark$ & $\checkmark$ & $\checkmark$ & $\checkmark$ & $x$ & $x$ & $\checkmark$ & $\checkmark$ & $\checkmark$ & $\checkmark$ & $\begin{array}{c}86.66 \\
\text { Strong } \\
\text { Evidence }\end{array}$ \\
\hline
\end{tabular}

Point awarded X Point not awarded. 